\title{
Sex Differences in Molecular Signaling at Inhibitory Synapses in the Hippocampus
}

\author{
Nino Tabatadze, Guangzhe Huang, Renee M. May, ${ }^{-A n a n t}$ Jain, and Catherine S. Woolley \\ Department of Neurobiology, Northwestern University, Evanston, Illinois 60208
}

The possibility that mechanisms of synaptic modulation differ between males and females has far-reaching implications for understanding brain disorders that vary between the sexes. We found recently that $17 \beta$-estradiol (E2) acutely suppresses GABAergic inhibition in the hippocampus of female rats through a sex-specific estrogen receptor $\alpha(\mathrm{ER} \alpha)$, mGluR, and endocannabinoid-dependent mechanism. Here, we define the intracellular signaling that links $\mathrm{ER} \alpha$, mGluRs, and endocannabinoids in females and identify where in this pathway males and females differ. Using a combination of whole-cell patch-clamp recording and biochemical analyses in hippocampal slices from young adult rats, we show that $\mathrm{E} 2$ acutely suppresses inhibition in females through mGluR1 stimulation of phospholipase $\mathrm{C}$, leading to inositol triphosphate $\left(\mathrm{IP}_{3}\right)$ generation, activation of the $\mathrm{IP}_{3}$ receptor $\left(\mathrm{IP}_{3} \mathrm{R}\right)$, and postsynaptic endocannabinoid release, likely of anandamide. Analysis of sex differences in this pathway showed that $\mathrm{E} 2$ stimulates a much greater increase in $\mathrm{IP}_{3}$ levels in females than males, whereas the group I mGluR agonist DHPG increases $\mathrm{IP}_{3}$ levels equivalently in each sex. Coimmunoprecipitation showed that ER $\alpha-$ mGluR1 and mGluR1-IP $R$ R complexes exist in both sexes but are regulated by E2 only in females. Independently of E2, a fatty acid amide hydrolase inhibitor, which blocks breakdown of anandamide, suppressed $>50 \%$ of inhibitory synapses in females with no effect in males, indicating tonic endocannabinoid release in females that is absent in males. Together, these studies demonstrate sex differences in both E2-dependent and E2-independent regulation of the endocannabinoid system and suggest that manipulation of endocannabinoids in vivo could affect physiological and behavioral responses differently in each sex.

Key words: endocannabinoid; estradiol; GABA; metabotropic glutamate receptor

\section{Significance Statement}

Many brain disorders vary between the sexes, yet the degree to which this variation arises from differential experience versus intrinsic biological sex differences is unclear. In this study, we demonstrate intrinsic sex differences in molecular regulation of a key neuromodulatory system, the endocannabinoid system, in the hippocampus. Endocannabinoids are involved in diverse aspects of physiology and behavior that involve the hippocampus, including cognitive and motivational state, responses to stress, and neurological disorders such as epilepsy. Our finding that molecular regulation of the endocannabinoid system differs between the sexes suggests mechanisms through which experiences or therapeutics that engage endocannabinoids could affect males and females differently.

\section{Introduction}

Being male or female contributes to the risk of developing neuropsychiatric or neurological disorders. Many brain disorders, including anxiety and depression (Altemus et al., 2014), autism spectrum disorders (Werling and Geschwind, 2013), stroke (Herson et al., 2013),

\footnotetext{
Received March 18, 2015; revised June 5, 2015; accepted June 30, 2015

Author contributions: N.T. and C.S.W. designed research; N.T., G.H., R.M.M., and A.J. performed research; N.T., G.H., R.M.M., and C.S.W. analyzed data; N.T. and C.S.W. wrote the paper.

This research was supported by National Institutes of Health Grant R01 NS037324, the Office for Research on Women's

Health, and the Northwestern University Biological Imaging Facility and High Throughput Analysis Facility.

The authors declare no conflicts of interest.

Correspondence should be addressed to Dr. Catherine S. Woolley, 2205 Tech Drive, Evanston, IL 60208. E-mail: cwoolley@northwestern.edu.

DOI:10.1523/JNEUROSCI.1067-15.2015

Copyright $\odot 2015$ the authors $\quad 0270-6474 / 15 / 3511252-14 \$ 15.00 / 0$
}

and epilepsy (Savic and Engel, 2014) vary between the sexes in their incidence, clinical manifestations, and/or therapeutic response. How these sex differences arise, for example through differential experience and/or biological differences in the brain intrinsic to one sex or the other, is largely unknown. The possibility of intrinsic sex differences has far-reaching implications for understanding normal brain functions, as well as for the study, diagnosis, and treatment of brain disorders that differ between the sexes.

There is growing awareness that a key modulatory system in the brain, the endocannabinoid (eCB) system, may differ between males and females (Wiley et al., 2008; Reich et al., 2009; Atkinson et al., 2010). eCBs are lipid-derived neuromodulators that influence cognitive, emotional, and motivational states (Zanettini et al., 2011), pain (Maione et al., 2013), responses to stress (Hill and Patel, 2013), 
and neurological disorders such as epilepsy (Alger, 2004). At a cellular level, eCBs act as retrograde messengers that are released from a postsynaptic neuron to inhibit presynaptic neurotransmitter release from inputs that express cannabinoid receptor $1\left(\mathrm{CB}_{1} \mathrm{R}\right)$. The two primary eCBs in the brain, 2-arachidonylglycerol (2-AG) and $\mathrm{N}$-arachidonylethanolamide (AEA, also known as anandamide), are produced tonically or "on demand" by changes in neural activity. Depending on the pattern of activity, eCBs can produce transient or persistent decreases in neurotransmitter release (Castillo et al., 2012).

We recently discovered a sex-specific mechanism of persistent eCB-mediated synaptic modulation in the hippocampus (Huang and Woolley, 2012). Using acute application of $17 \beta$-estradiol (E2) to hippocampal slices as a model for neurosteroid E2 actions in the brain, we found that E2 suppresses perisomatic inhibitory synaptic transmission within minutes, specifically in females with no effect in males. This is in contrast to acute E2-induced potentiation of excitatory synaptic transmission, which occurs in both sexes (Kramár et al., 2009; Smejkalova and Woolley, 2010). Additional studies showed that E2-induced suppression of inhibition is mediated by the $\alpha$ form of the estrogen receptor (ER $\alpha)$ and requires $\mathrm{CB}_{1} \mathrm{Rs}$, indicating the involvement of eCBs. Consistent with the fact that only a subset of inhibitory inputs in the hippocampus expresses $\mathrm{CB}_{1} \mathrm{Rs}$ and is therefore sensitive to eCBs (Katona et al., 1999), E2 suppresses inhibition in a subset of recordings $(\sim 55 \%)$.

Similar to the most commonly studied form of persistent eCB-mediated synaptic depression, long-term depression of inhibition (iLTD; Chevaleyre and Castillo, 2003), E2-induced suppression of inhibition requires group I mGluR activation (Huang and Woolley, 2012). However, beyond this, little is known about the molecular steps that link E2 activation of ER $\alpha$ to eCB synthesis, or what accounts for the sex specificity of E2-induced suppression of inhibition. Therefore, the goals of the current study were twofold: (1) to define the intracellular signaling that underlies acute E2-induced suppression of inhibition; and (2) to identify where in this pathway males and females differ.

\section{Materials and Methods}

Animals and preparation of hippocampal slices. All experiments were done with gonadectomized young adult (47-57 d of age) male and female Sprague Dawley rats (Harlan). Rats were group housed on a $12 \mathrm{~h}$ light/ dark cycle with ad libitum access to water and phytoestrogen-free chow. All animal procedures were performed in accordance with the National Institutes of Health Guide to the Care and Use of Laboratory Animals and were approved by the Northwestern University Animal Care and Use Committee. Females were ovariectomized bilaterally under ketamine ( 85 $\mathrm{mg} / \mathrm{kg}) /$ xylazine $(13 \mathrm{mg} / \mathrm{kg})$ anesthesia and used for experiments 3-7 d after surgery. Males were castrated under the same anesthesia and also were used 3-7 d after surgery. For electrophysiology and biochemistry experiments, rats were anesthetized with sodium pentobarbital (125 mg/ $\mathrm{kg}$, i.p.) and perfused transcardially with ice-cold oxygenated (95\% $\mathrm{O}_{2} / 5 \% \mathrm{CO}_{2}$ ) sucrose artificial CSF (aCSF) containing the following (in mM): 75 sucrose, $75 \mathrm{NaCl}, 2 \mathrm{KCl}, 25 \mathrm{NaHCO}_{3}, 1.25 \mathrm{NaH}_{2} \mathrm{PO}_{4}, 2.4 \mathrm{Na}$ pyruvate, 1.3 ascorbic acid, $3 \mathrm{MgCl}_{2}, 0.5 \mathrm{CaCl}_{2}$, and 15 dextrose, $\mathrm{pH}$ 7.4. The brain was removed quickly, and $300 \mu \mathrm{m}$ transverse hippocampal slices were cut using a VT1200S vibratome (Leica). Slices were allowed to recover for $30-60 \mathrm{~min}$ at $34-35^{\circ} \mathrm{C}$ in oxygenated regular aCSF containing the following (in mM): $126 \mathrm{NaCl}, 3 \mathrm{KCl}, 26 \mathrm{NaHCO}_{3}, 1.25 \mathrm{NaH}_{2} \mathrm{PO}_{4}$, $1 \mathrm{MgCl}_{2}, 2 \mathrm{CaCl}_{2}$, and 10 dextrose, $\mathrm{pH} 7.5$ and then were treated for biochemical experiments or maintained in regular aCSF at room temperature $\left(20-22^{\circ} \mathrm{C}\right)$ until used for electrophysiological recording or single-cell PCR. For electron microscopy, female rats were anesthetized with sodium pentobarbital and perfused transcardially with $2 \%$ paraformaldehyde $/ 2 \%$ glutaraldehyde in $0.1 \mathrm{M}$ phosphate buffer (PB). Brains were removed, blocked to contain the hippocampus, postfixed overnight at $4^{\circ} \mathrm{C}$, and then cryoprotected with $30 \%$ sucrose in PB.

Electrophysiological recording. Recordings of synaptically evoked $\mathrm{GABA}_{\mathrm{A}}$ receptor-mediated IPSCs from CA1 pyramidal cells were performed as described previously (Huang and Woolley, 2012). Each slice was transferred to a submersion chamber mounted on a Zeiss Axio Examiner microscope equipped with a water-immersion $40 \times / 1.0$ differential interference contrast (DIC) objective and was continuously perfused at $1.5-2.0 \mathrm{ml} / \mathrm{min}$ with oxygenated regular aCSF at $34-35^{\circ} \mathrm{C}$. CA1 pyramidal cells were visualized using a Sensicam QE CCD camera. Whole-cell patch-clamp recordings were obtained using a MultiClamp 700B amplifier (Molecular Devices) and Clampex 10.2 software (Molecular Devices). Signals were low-pass filtered at $2 \mathrm{kHz}$ and sampled at $5 \mathrm{kHz}$ with a DigiData 1440A interface (Molecular Devices). Recording electrodes had tip resistances ranging from 4 to $6 \mathrm{M} \Omega$ when filled with internal solution, which contained the following (in $\mathrm{mm}$ ): $110 \mathrm{~K}$-gluconate, 25 $\mathrm{KCl}, 10 \mathrm{HEPES}, 0.2 \mathrm{EGTA}, 2 \mathrm{MgATP}, 0.3 \mathrm{NaGTP}$, and $10 \mathrm{Na}_{2}$-creatinine phosphate, $\mathrm{pH}$ 7.2-7.3. In some experiments, AM404 [N-(4-hydroxyphenyl)-arachidonamide ( $2 \mu \mathrm{M})$ ] or BAPTA [1,2-bis(o-aminophenoxy) ethane-N,N, $\mathrm{N}^{\prime}, \mathrm{N}^{\prime}$-tetraacetic acid) $\left.(20 \mathrm{~mm})\right]$ was included in the recording pipette. IPSCs were evoked via a glass bipolar stimulating electrode $(10-20 \mu \mathrm{m}$ tip) placed in the CA1 pyramidal cell layer $30-150 \mu \mathrm{m}$ from the recording electrode and were recorded in the presence of DNQX [6,7-dinitroquinoxaline-2,3-dione $(10 \mu \mathrm{M})$ ], DL-APV [DL-2amino-5-phosphonopentanoic acid $(50 \mu \mathrm{M})]$, and CGP55845 [(2S)-3[(15)-1-(3,4-dichlorophenyl)ethyl]amino-2-hydroxypropyl)(phenylmethyl) phosphinic acid $(1 \mu \mathrm{M})$ ]. The $\mathrm{GABA}_{\mathrm{A}}$ receptor antagonist SR 95531 [2(3-carboxypropyl)-3-amino-6-(4-methoxyphenyl)pyridazinium bromide $(2 \mu \mathrm{M})]$ was applied at the end of each experiment. In most experiments, paired stimulations $(0.1 \mathrm{~ms})$ were delivered at $0.067 \mathrm{~Hz}$ with a $100 \mathrm{~ms}$ interstimulus interval using a WPI stimulus isolation unit. For theta-burst firing (TBF)-iLTD experiments, each TBF episode consisted of 10 bursts of five action potentials at $50 \mathrm{~Hz}$, delivered at $5 \mathrm{~Hz}$; TBF-iLTD was induced by delivering 60 TBF episodes, one every $5 \mathrm{~s}$ (Younts et al., 2013). To measure depolarization-induced suppression of inhibition (DSI), cells were depolarized to $0 \mathrm{mV}$ for $5 \mathrm{~s}$. Stock solutions were prepared in DMSO or $\mathrm{ddH}_{2} \mathrm{O}$ and were diluted in aCSF on the day of recording to the final concentrations indicated. Control aCSF contained an equivalent concentration of DMSO $(<0.1 \%)$. Drug and/or E2 effects were assessed by averaging IPSCs recorded during the last $2 \mathrm{~min}$ before drug application to those recorded during the last $2 \mathrm{~min}$ in each condition. CGP55845, SR 95531, U73343 [(1-[6-((17ß)-3-methoxyestra1,3,5(10)-trien-17-yl)amino)hexyl]-2,5-pyrrolidine-dione)], U73122 [(1[6[[(17 $\beta$ )-3-methoxyestra-1,3,5(10)-trien-17-yl] amino $]$ hexyl]-1 $H$-pyrrole2,5-dione)], JNJ 16259685 [(3,4-dihydro- $2 H$-pyrano[2,3] $\beta$-quinolin-7yl)(cis-4-methoxycyclohexyl) methanone)], Xestospongin C (Xest), DHPG [(RS)-3,5-dihydroxyphenylglycine], AM404, and BAPTA were purchased from Tocris Bioscience. E2 and URB597 [3'-(aminocarbonyl) [1,1'-biphenyl]-3-yl)-cyclohexylcarbamate] were purchased from Sigma.

Measurement of inositol triphosphate levels. Each inositol triphosphate $\left(\mathrm{IP}_{3}\right)$ experiment used hippocampal slices from male and female rats split evenly between treatment groups and time points within sex; $12-14$ slices from each rat were used in each experiment, with a total of four slices per treatment/time point. After recovery at $34-35^{\circ} \mathrm{C}$ in oxygenated regular aCSF, the solution was replaced with fresh aCSF containing vehicle or treatment for various times, as indicated for each experiment. After treatment, slices were transferred immediately to HEPES homogenization buffer containing (in mM): 5 HEPES-KOH, pH 7.2, 320 sucrose, 5 EDTA, $1 \mathrm{Na}$ orthovanadate, $50 \mathrm{NaF}, 10 \mathrm{Na}$ pyrophosphate, $20 \mathrm{Na}$ glycerophosphate, 0.1 phenylmethylsulfonyl fluoride, plus the protease inhibitors leupeptin and aprotinin at $1 \mu \mathrm{g} / \mathrm{ml}$ each and $0.2 \mathrm{~N}$ perchloric acid to stabilize $\mathrm{IP}_{3}$. Hippocampi were dissected quickly from each slice on ice, sonicated (two times, $3 \mathrm{~s}$ pulses) in homogenization buffer, and processed immediately for $\mathrm{IP}_{3}$ assay.

Intracellular levels of $\mathrm{IP}_{3}$ were measured using a Hit-Hunter IP3 Fluorescence Polarization Assay kit (DiscoveRx) according to the instructions of the manufacturer. Cell lysates or $\mathrm{IP}_{3}$ standards were pipetted into a 384-well plate with a nonbinding surface. The $\mathrm{IP}_{3} \operatorname{tracer}(10 \mu \mathrm{l})$ was 
added to each well, followed by the addition of $\mathrm{IP}_{3}$ binding protein $(40$ $\mu \mathrm{l})$. The plate was incubated for $30 \mathrm{~min}$ at room temperature in the dark on a shaker, and then the fluorescence polarization signal of the $\mathrm{IP}_{3}$ tracer was detected by a multimode microplate reader (Analyst) with a fluorescence polarization filter, using $485 \mathrm{~nm}$ excitation and $530 \mathrm{~nm}$ emission wavelengths. The $\mathrm{IP}_{3}$ concentration in each sample was calculated from a standard curve generated with sigmoidal curve fitting.

Coimmunoprecipitation. Each coimmunoprecipitation (co-IP) experiment used slices from four male and four female rats, 12-14 slices per rat, split evenly between treatment groups within sex. After recovery at $34-35^{\circ} \mathrm{C}$ in oxygenated regular aCSF, slices were treated with either vehicle or E2 (100 nM) in oxygenated regular aCSF at room temperature for $10 \mathrm{~min}$. After treatment, hippocampi were dissected from each slice and sonicated on ice in HEPES homogenization buffer containing protease inhibitors as above. Tissue homogenates were centrifuged at $1000 \times g$ for $10 \mathrm{~min}$ to remove unbroken cells and nuclei. Membrane fractions were prepared by ultracentrifugation of postnuclear supernatant at 100,000 $\times$ $g$ for $1 \mathrm{~h}$ at $4^{\circ} \mathrm{C}$ using a fixed angle rotor. Protein concentration was determined using the Bradford protein assay.

Co-IP was performed using a Pierce co-IP kit according to the instructions of the manufacturer. Briefly, $15 \mu \mathrm{g}$ of primary mouse anti-mGluR1 monoclonal (BD Biosciences) or rabbit anti-mGluR5 polyclonal (Millipore) antibodies were coupled to AminoLink resin containing A/G magnetic beads for $2 \mathrm{~h}$ at room temp. After extensive washing to remove unbound antibodies, beads were used for lysate application. All protein samples were first precleared using control beads, and then $300 \mu \mathrm{g}$ of total protein for each sample was incubated with antibody-coupled beads on a rotator at $4^{\circ} \mathrm{C}$ overnight. Samples were washed three times and eluted by adding Laemmli sample buffer and boiling for $5 \mathrm{~min}$. No lysate and no antibody controls were included in each experiment.

Western blotting. Immunoprecipitated samples along with input samples were resolved on 6-10\% SDS-PAGE gels and transferred to PVDF membranes. Membranes were blocked with 5\% nonfat milk and then incubated with one of the following primary antibodies overnight at $4^{\circ} \mathrm{C}$ : mouse monoclonal anti-mGluR1 (1:2000; BD Biosciences), rabbit-polyclonal antimGluR5 (1:1000; Millipore), rabbit-polyclonal anti-ER $\alpha$ (1:1000, MC-20; Santa Cruz Biotechnology), rabbit polyclonal anti-IP ${ }_{3}$ receptor $\left(\mathrm{IP}_{3} \mathrm{R}\right.$; 1:1000; Cell Signaling Technology), rabbit polyclonal anti-Homer-1b/c (1: 2000; Santa Cruz Biotechnology), or rabbit polyclonal anti-PSD-95 (1:500; Cell Signaling Technology). Membranes were washed in TBS and then in $0.1 \%$ Tween 20 in TBS and incubated at room temperature for $1 \mathrm{~h}$ with horseradish peroxidase-conjugated anti-mouse or anti-rabbit IgG secondary antibodies (1:1000; Vector Laboratories). Immunoreactivity was visualized using an enhanced chemiluminescence kit (ECL Plus). Films were

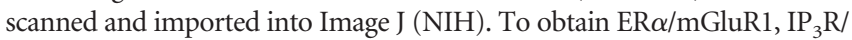
mGluR1, and Homer-1b/c/mGluR1 ratios, the OD value of each IP sample band was divided by the OD value of its corresponding input run on the same gel, and then $\mathrm{ER} \alpha, \mathrm{IP}_{3} \mathrm{R}$, and Homer- $1 \mathrm{~b} / \mathrm{c}$ values were divided by mGluR1 values from the same sample.

Electron microscopy. Tissue from three ovariectomized female rats was prepared for immunoelectron microscopy as described previously (Hart et al., 2007). Briefly, tissue blocks containing the dorsal hippocampus were sectioned at $50 \mu \mathrm{m}$ using an SM20000R freezing microtome (Leica). Sections were labeled with anti-ER $\alpha$ rabbit polyclonal MC-20 (0.5 $\mu \mathrm{g} / \mathrm{ml}$; Santa Cruz Biotechnology), incubated with anti-rabbit biotinylated IgG (1:800; Vector Laboratories), and visualized with DAB using an $\mathrm{ABC}$ kit (Vector Laboratories). Sections were then stained with $1 \%$ osmium tetroxide and flat embedded in Eponate resin (Ted Pella). The CA1 region was then dissected from flat-embedded sections and mounted onto BEEM capsules. Series of ultrathin $(\sim 75 \mathrm{~nm})$ sections were cut using a Reichert Ultracut $S$ ultramicrotome (Leica), collected onto Formvar-coated slot grids, stained with 3\% uranyl acetate followed by $2.66 \%$ Reynold's lead citrate, and imaged with a JEOL 1230 transmission electron microscope equipped with a CCD camera. For each brain, a low-magnification image $(400 \times)$ of the first section in a series was used to select two regions in the CAl cell body layer using a random systematic approach. Then, five CA1 pyramidal cell somata within each region (10 per brain) were imaged $(20,000 \times)$ through five consecutive sections, and images were examined offline for sites of extranuclear ER $\alpha$ immunoreactivity.
Single-cell nested PCR. Cell collection for single-cell PCR was performed according to the study by Citri et al. (2012) using hippocampal slices from eight female rats prepared as for electrophysiology experiments. The cell bodies of putative CA1 pyramidal cells or interneurons were identified using DIC imaging. A patch pipette with a tip diameter of $1.8-2.0 \mu \mathrm{m}$ was lowered to the slice with slight positive pressure. Once the pipette tip touched a targeted cell, pressure was relieved and slight suction was applied for gradual aspiration of the cell body. The pipette was withdrawn, and positive pressure was used to expel the contents into a PCR tube containing $4 \mu \mathrm{l}$ of ultrapure nuclease-free water. Each sample was frozen immediately on dry ice.

Nested PCR was conducted in two steps using separate primer pairs for each step. Primers were designed using the Primer-BLAST designing tool (NIH) and are shown in Table 1, which includes sequences, target locations, and amplicon sizes. In the first step, reverse transcription (RT)PCR was used to amplify longer fragments from each gene of interest, which was followed by real-time PCR targeting sequences within the amplicons generated by the first RT-PCR step. RT reactions for each cell were performed using the GoScript Reverse Transcription System (Pro-

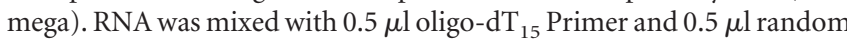
primers. Samples were incubated at $70^{\circ} \mathrm{C}$ for $5 \mathrm{~min}$, followed by immediate chilling on ice for $5 \mathrm{~min}$. The RT master mix consisted of $2 \mu \mathrm{l}$ of GoScript $5 \times$ reaction buffer, $1.5 \mu \mathrm{l}$ of $\mathrm{MgCl}_{2}, 0.5 \mu \mathrm{l}$ of PCR nucleotide mix, $0.25 \mu \mathrm{l}$ of recombinant RNasin, and $0.5 \mu \mathrm{l}$ of GoScript reverse transcriptase and was added to each sample for a total volume of $10 \mu \mathrm{l}$. Samples were incubated at $25^{\circ} \mathrm{C}$ for $5 \mathrm{~min}, 42^{\circ} \mathrm{C}$ for $1 \mathrm{~h}$, and $70^{\circ} \mathrm{C}$ for 15 min. The resulting cDNAs were then subjected to multiplex PCR amplification (Price et al., 2005) using all first PCR primer pairs shown in Table 1. Each PCR reaction contained $8 \mu \mathrm{l}$ of cDNA, $0.08 \mu \mathrm{l}$ of each forward primer $(0.3 \mu \mathrm{M}), 0.08 \mu \mathrm{l}$ of each reverse primer $(0.3 \mu \mathrm{M}), 12.5 \mu \mathrm{l}$ of GoTaq colorless master mix (Promega), and $2.5 \mu \mathrm{l}$ nuclease-free water for a total volume of $25 \mu \mathrm{l}$, and 20 cycles were run $\left(95^{\circ} \mathrm{C}, 30 \mathrm{~s} ; 62^{\circ} \mathrm{C}, 30\right.$ $\min ; 72^{\circ} \mathrm{C}, 1 \mathrm{~min}$ ). After the first PCR step, samples were cleaned by adding $10 \mu \mathrm{l}$ of ExoSAP-IT (Affymetrix) and were returned to the PCR machine for $15 \mathrm{~min}$ at $37^{\circ} \mathrm{C}$ to digest primers and dNTPs, followed by 15 $\min$ at $80^{\circ} \mathrm{C}$ to denature the enzyme. Samples were then spun down briefly and diluted (1:100) in nuclease-free water for subsequent realtime PCR.

Real-time PCR for the second step was run in duplicates in a 384-well plate by mixing $1.2 \mu \mathrm{l}$ of cDNA and $1.2 \mu \mathrm{l}$ of GoTaq real-time PCR master mix (Promega) using a Mosquito LCP automated liquid handler (TTP Labtech) and then adding $10 \mathrm{nl}$ of each primer pair mix (200 nM each primer) with an Echo Liquid Handler (Labcyte). PCR was performed using the following program: $95^{\circ} \mathrm{C}$ for $5 \mathrm{~min}, 40$ cycles of $95^{\circ} \mathrm{C}$ for $15 \mathrm{~s}$, and $62^{\circ} \mathrm{C}$ for $1 \mathrm{~min}$, followed by a melt curve analysis $\left(95^{\circ} \mathrm{C}\right.$ for $15 \mathrm{~s}$, 62 to $95^{\circ} \mathrm{C}$ with $0.5^{\circ} \mathrm{C}$ intervals, 30 s per interval).

To determine primer specificity, mRNA was isolated from whole hippocampus of a female rat using a Purelink RNA Mini Kit (Ambion) according to the instructions of the manufacturer. The nested PCR products were run on a $2 \%$ agarose gel at $120 \mathrm{~V}$ for $1 \mathrm{~h}$ and viewed with a gel imager (Bio-Rad). To assess nested primer efficiencies for real-time PCR, four sequential dilutions (0.01-10 ng) of cDNA derived from whole hippocampal mRNA were run in duplicate. Amplification efficiencies for all primer pairs were between 98 and $100 \%$. Based on the standard curve generated for determination of primer efficiencies, the limit of detection for each PCR product was determined (Caraguel et al. 2011) and used to set an overall detection threshold of $\mathrm{Ct} \leq 35$. Thus, for each cell, PCR products that were detected within 35 cycles were designated as + , and targets that showed no amplification or required $>35$ cycles were designated as - . The following controls were included each time single-cell nested PCR was run: no cDNA, aCSF alone, and cell contents without RT to exclude the possibility that the primers amplified nuclear DNA. None of these controls resulted in amplification of any target.

Statistical analyses. All data are reported as mean \pm SEM. For electrophysiological experiments, $n$ is the number of cells, with one to two cells recorded per animal. For biochemical experiments, $n$ is the number of independent runs of each experiment. The Shapiro-Wilk test was used to determine that data were normally distributed. Statistical comparisons for electrophysiology and co-IP results were made using two-tailed 
Table 1. Primers used for both steps of nested PCR, including sequences, target locations, and amplicon sizes

\begin{tabular}{|c|c|c|c|c|c|}
\hline$\overline{\text { Gene }}$ & GenBank accession number & First $P C R$ primers & Size (bp) & Second nested PCR primers & Size (bp) \\
\hline \multirow[t]{2}{*}{ GAPDH } & \multirow[t]{2}{*}{ NM_017008.4 } & Sense, 373: TTCACCACCATGGAGAAGGC & \multirow[t]{2}{*}{321} & Sense, 468: GGGTGTGAACCACGAGAAATA & \multirow[t]{2}{*}{104} \\
\hline & & Antisense, 693: AGGGATGATGTTCTGGGCTG & & Antisense, 571: AGTTGTCATGGATGACCTTGG & \\
\hline HPRT & NM_012583.2 & Sense, 514: GTCAAGCAGTACAGCCCCAA & 256 & Sense, 567: GACCTCTCGAAGTGTTGGATAC & 107 \\
\hline \multirow[t]{2}{*}{ mGluR1 (pan) } & \multirow[t]{2}{*}{ NM_017011.1 } & Sense, 1652: AACATGCACCATGCTCTGTG & \multirow[t]{2}{*}{205} & Sense, 1682: GTGGGCCTGTGTGATGCTAT & \multirow[t]{2}{*}{93} \\
\hline & & Antisense, 1856: AGTCATAGCGATTAGCTTCTGTG & & Antisense, 1774: СTCCTCTCCAGACACTCCGA & \\
\hline mGluR1a-1 & NM_017011.1 & Sense, 2934: CTGATGTTGTCCGCATGCAC & 210 & Sense, 2934: CTGATGTTGTCCGCATGCAC & 113 \\
\hline mGluR1a-2 & NM_017011.1 & Antisense, 3143: CCGTCTCGTTGGTCTTCACG & 210 & Antisense, 3143: CCGTCTCGTTGGTCTTCACG & 118 \\
\hline \multirow[t]{2}{*}{ mGluR1a-3 } & \multirow[t]{2}{*}{ NM_017011.1 } & Sense, 5662: TCTCTTCCTTATGATCCTCATGTGT & \multirow[t]{2}{*}{276} & Sense, 5843: TGTGAGATGAACCCGTTCCC & \multirow[t]{2}{*}{91} \\
\hline & & Antisense, 5937: AGAAACCAGCAGCTTCGACA & & Antisense, 5933: ACCAGCAGCTTCGACATGAA & \\
\hline \multirow[t]{2}{*}{ mGluR1a-4 } & \multirow[t]{2}{*}{ NM_017011.1 } & Sense, 5662: TCTCTTCCTTATGATCCTCATGTGT & \multirow[t]{2}{*}{276} & Sense, 5781: TGACCCTACCTTTTCGAACCC & \multirow[t]{2}{*}{92} \\
\hline & & Antisense, 5937: AGAAACCAGCAGCTTCGACA & & Antisense, 5872: ACCCGTTCCCTTTAAATAAT & \\
\hline mGluR5 & NM_017012.1 & Sense, 2711: GCATGTTTGTCCCGAAGGTG & 231 & Sense, 2797: ATGCATGTAGGAGACGGCAA & 110 \\
\hline & & Antisense, 2119: TGGCTGGACGCAGTAGATTC & & Antisense, 2004: ACCCCTAACATTGACTGGAGC & \\
\hline GAD65 & NM_012563.1 & Sense, 771: GGCTCTGGCGATGGAATCTT & 306 & Sense, 798: GGTGGTGCCATCTCCAACAT & 116 \\
\hline & & Antisense, 1076: GGCACTCACCAGGAAAGGAA & & Antisense, 913: TGCTCTGACGTGAATGCGAT & \\
\hline GFAP & NM_017009.2 & Sense, 961: GAGTTACCAGGAGGCACTCG & 300 & Sense, 1098: AATTGCTGGAGGGCGAAGAA & 112 \\
\hline & & Antisense, 1260: TTAATGACCTCGCCATCCCG & & Antisense, 1209: TTGAGGTGGCCTTCTGACAC & \\
\hline
\end{tabular}

In the first step of nested PCR, RT-PCR was used to amplify longer fragments from each gene of interest, which was followed by real-time PCR targeting sequences within the amplicons generated by the first RT-PCR step.

paired Student's $t$ tests. For IP ${ }_{3}$ levels, two-way mixed ANOVA and oneway ANOVA were followed by Tukey's post hoc tests. Distributions of responsive and nonresponsive cells were compared using $\chi^{2}$ tests. Significance was determined at $p<0.05$.

\section{Results}

\section{E2 occludes mGluR-mediated suppression of inhibition}

We first verified the effect of E2 to suppress a subset of inhibitory synapses in females and tested whether these are the same synapses suppressed by group I mGluR activation, which is known to stimulate eCB synthesis (Ohno-Shosaku et al., 2002). We recorded IPSCs in CA1 pyramidal cells evoked by paired-pulse stimulation in the cell body layer and applied E2 (100 nM) either before or in the presence of the group I mGluR agonist DHPG (50 $\mu \mathrm{M})$. In five of nine recordings (55\%) in which E2 was applied first (Fig. 1A), E2 rapidly decreased IPSC amplitude by $54 \pm 3 \%$, and DHPG applied after E2 produced no additional decrease $(-8 \pm 5 \%$; Fig. $1 B)$, demonstrating that E2 occluded DHPGinduced suppression of inhibition. In parallel with decreasing IPSC amplitude, E2 increased the paired-pulse ratio (PPR; $p<$ 0.01 ), indicating reduced presynaptic GABA release probability, and DHPG applied after E2 did not increase PPR any further (Fig. $1 C)$. In the four recordings in which $\mathrm{E} 2$ had no effect on IPSC amplitude (2 $\pm 3 \%$; Fig. $1 D)$ or PPR, DHPG also had no effect on IPSC amplitude $(4 \pm 3 \%)$ or PPR. In the converse experiment, DHPG was applied before E2 (Fig. $1 E$ ). In 8 of 13 recordings (62\%), DHPG decreased IPSC amplitude by $47 \pm 4 \%$ (Fig. $1 F$ ) and increased PPR ( $p<0.05$; Fig. $1 G)$, and E2 applied in the presence of DHPG had no additional effect on IPSC amplitude $(-8 \pm 2 \%$; Fig. $1 F)$ or PPR (Fig. $1 G$ ). In the five recordings that did not respond to DHPG, E2 also had no effect on IPSC amplitude $(-0.6 \pm 3 \%$; Fig. $1 H)$ or PPR.

Together, these experiments showed that E2 and group I mGluR activation each mimic and occlude the effects of the other to suppress inhibition. Because E2-nonresponsive IPSCs also showed no response to DHPG and vice versa, the subset of inhib- itory synapses that is suppressed by E2 is likely the same subset that is suppressed by group I mGluR activation.

\section{E2 occludes eCB-mediated iLTD triggered by TBF}

E2-induced IPSC suppression is blocked by a $\mathrm{CB}_{1} \mathrm{R}$ antagonist and occluded by a $\mathrm{CB}_{1} \mathrm{R}$ agonist (Huang and Woolley, 2012), indicating that eCB signaling is involved. The mGluR dependence of E2's effect and its persistence after E2 washout resemble synaptically evoked iLTD, which lasts for at least $30 \mathrm{~min}$ after induction (Chevaleyre and Castillo, 2003). However, synaptically evoked iLTD in CA1 is typically induced using trains of stimulation in the dendritic layer and is restricted to dendritic synapses, where released glutamate can activate mGluRs. In contrast, E2-induced suppression of inhibition occurs at perisomatic synapses. Thus, to verify the effects of E2 to induce eCB-dependent suppression of perisomatic inhibitory synapses, we tested whether E2 occludes TBF-iLTD and vice versa. TBF-iLTD is a form of persistent eCB-dependent suppression of inhibitory synapses that affects both somatic and dendritic inputs (Younts et al., 2013).

In the first set of experiments, E2 (100 nM) was applied before TBF-iLTD was induced 15 min later (Fig. $2 A$ ). In 6 of 12 recordings (50\%), E2 decreased IPSC amplitude by $43 \pm 2 \%$ (Fig. $2 B$ ) and increased PPR ( $p<0.05$; Fig. $2 C)$. TBF after E2 failed to further affect IPSC amplitude $(-4 \pm 3 \%$ ) or PPR (Fig. $2 B, C$ ), indicating that $\mathrm{E} 2$ occluded TBF-iLTD. In the other six recordings, neither E2 nor TBF had any effect on IPSC amplitude (Fig. $2 D)$ or PPR. In the converse experiment, TBF-iLTD was induced first and then E2 $(100 \mathrm{nM})$ was applied $10 \mathrm{~min}$ later (Fig. 2E). In 6 of 15 recordings (40\%), TBF decreased IPSC amplitude by $40 \pm$ $4 \%$ (Fig. $2 F)$ and increased PPR $(p<0.01$; Fig. $2 G)$; E2 applied after TBF produced no additional decrease in IPSC amplitude $(2 \pm 3 \%)$ or change in PPR (Fig. $2 F, G$ ), showing that E2-induced suppression of inhibition was occluded by prior TBF. In seven recordings, TBF had no effect on IPSC amplitude ( $-1 \pm 2 \%)$, and E2 applied after TBF also had no effect on IPSCs (Fig. 2H). 
A
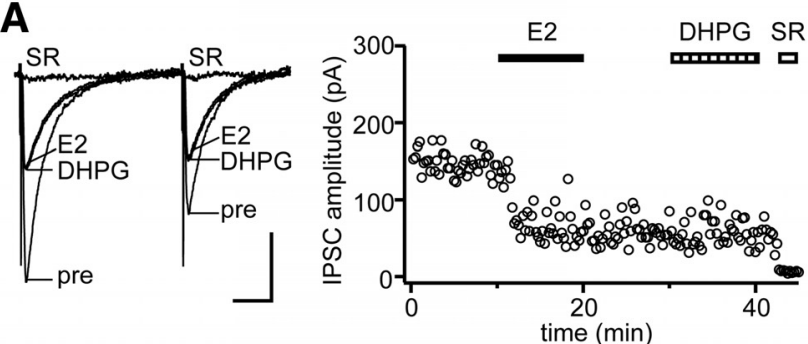

B

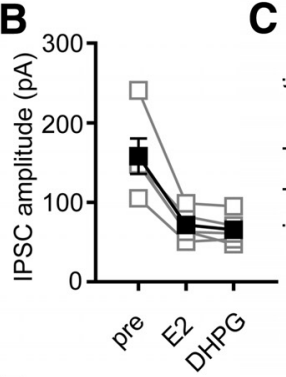

E
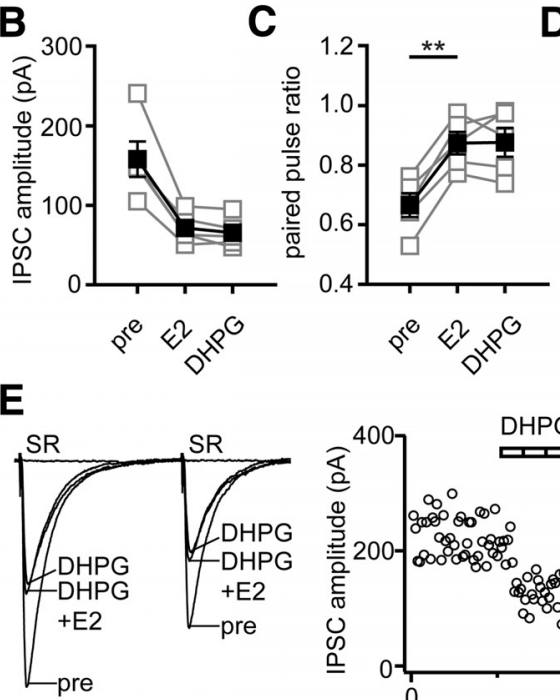

D
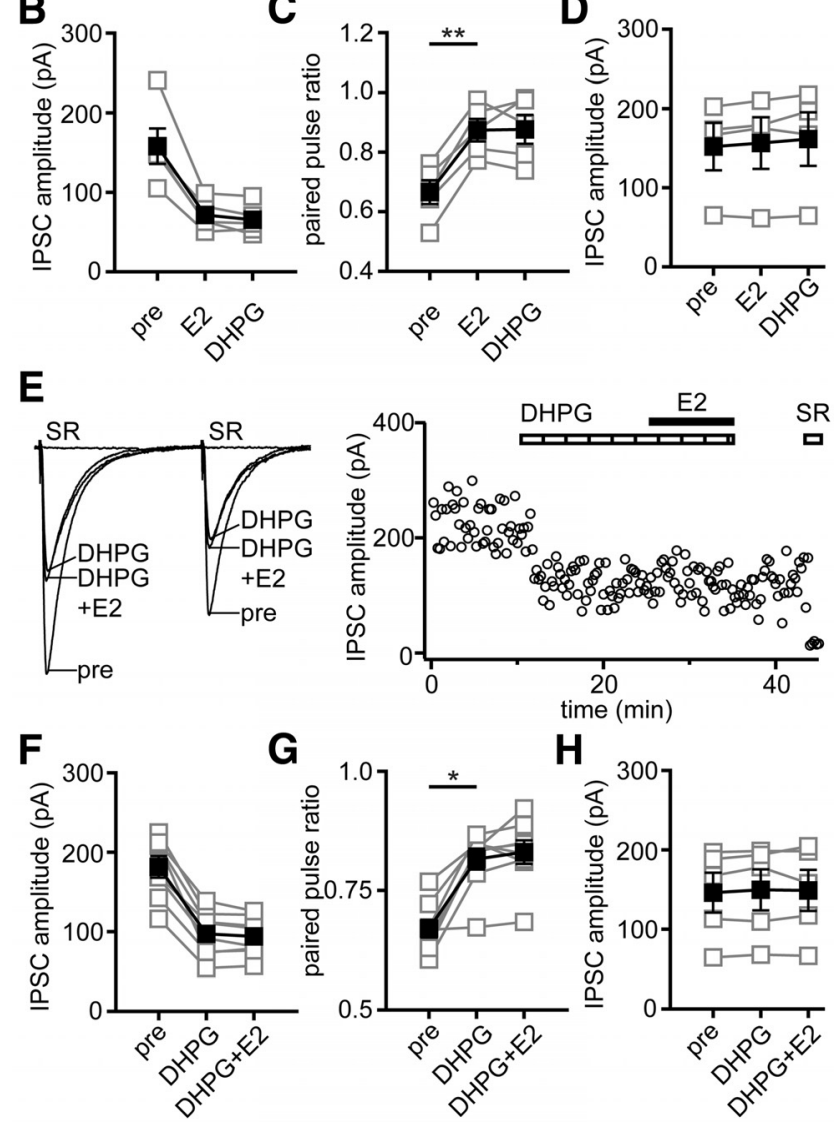

$\mathbf{H}$

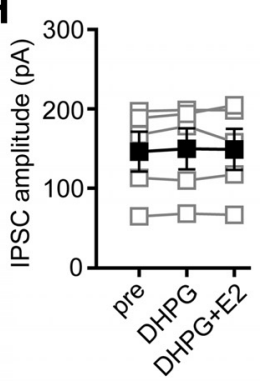

Figure 1. Mutual occlusion of E2- and DHPG-induced suppression of inhibition. $A$, Individual traces and time course of IPS ( suppression in a representative experiment in which E2 (100 nм) was applied before DHPG (group I mGluR agonist, $50 \mu \mathrm{m}$ ). E2 occluded DHPG-induced IPSC suppression. Each point in the time course is an individual sweep, and SR 95531 (SR; $2 \mu \mathrm{M}$ ) applied at the end of the experiment blocked IPSCs (also in E). B, Group IPSC amplitude data for experiments with E2-responsive IPSCS $(n=5)$. Connected open symbols are individual cells; filled symbols are mean \pm SEM for all cells (also in $\boldsymbol{C}, \boldsymbol{D}, \boldsymbol{F}-\boldsymbol{H}$ ). $\boldsymbol{C}$, Group PPR data for the same cells as in $\boldsymbol{B}_{;}{ }^{* *} p<0.01$, paired $t$ test. D, Group IPSC amplitude data for E2- and DHPGnonresponsive experiments $(n=4)$. $\boldsymbol{E}$, Individual traces and time course of IPSC suppression in a representative experiment in which DHPG was applied before E2. DHPG occluded E2-induced IPSC suppression. $\boldsymbol{F}$, Group IPSC amplitude data for all DHPG-responsive experiments $(n=8)$. $\mathbf{G}$, Group PPR data for the same cells as in $\boldsymbol{F} ;{ }^{*} p<0.05$, paired $t$ test. $\boldsymbol{H}$, Group IPSC amplitude data for DHPG-and E2-nonresponsive experiments $(n=5)$. Calibration: $A, 50 \mathrm{pA}, 25 \mathrm{~ms}$ (also applies to $E$ ).

However, in the remaining two recordings, there was a dissociation between TBF and E2 effects on IPSCs; in these experiments, TBF failed to decrease IPSC amplitude ( $1 \pm 2 \%)$, but E2 applied after TBF decreased IPSC amplitude by $39 \pm 8 \%$ and increased PPR from $0.5 \pm 0.05$ to $0.7 \pm 0.03$ (data not shown). Thus, with the exception of two (of 27) recordings, E2 and TBF each mimicked and occluded the effects of the other to suppress inhibition.

Together, these experiments corroborated previous evidence that E2-induced suppression of inhibition depends on group I
A
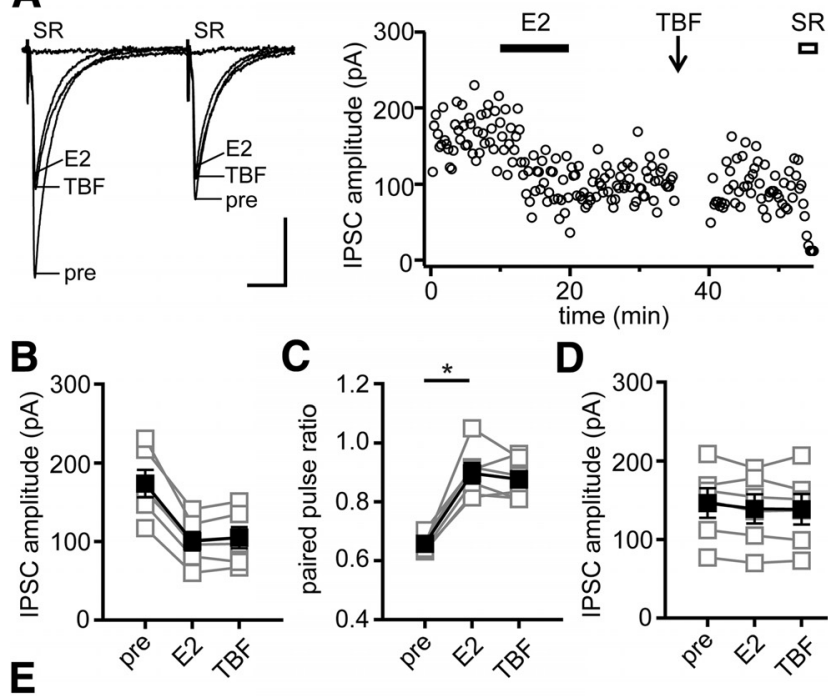

D
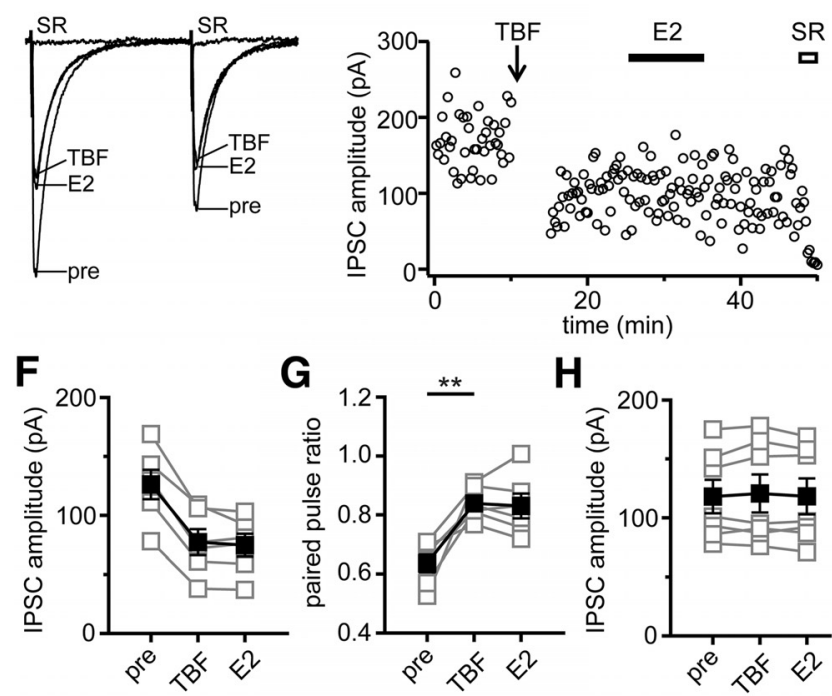

H

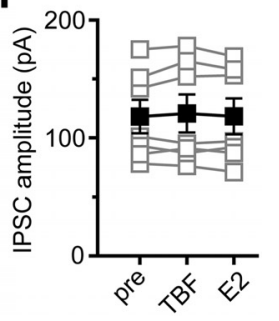

Figure 2. Mutual occlusion of E2- and TBF-induced suppression of inhibition. $A$, Individual traces and time course of IPSC suppression in a representative experiment in which E2 (100 nM) was applied before delivering TBF stimulation. E2 occluded TBF-induced iLTD. Each point in the time course is an individual sweep, and SR 95531 (SR;2 $\mu \mathrm{M}$ ) applied at the end of the experiment blocked IPSCs (also in E). $\boldsymbol{B}$, Group IPSC amplitude data for experiments with E2-responsive IPSCS $(n=6)$. Connected open symbols are individual cells; filled symbols are mean \pm SEM for all cells (also in $\boldsymbol{C}, \boldsymbol{D}, \boldsymbol{F}-\boldsymbol{H}$ ). $\boldsymbol{C}$, Group PPR data for the same cells as in $\boldsymbol{B} ;{ }^{*} p<0.05$, paired ttest. $\boldsymbol{D}$, Group IPSC amplitude data for E2- and TBF-nonresponsive experiments $(n=6)$. $\boldsymbol{E}$, Individual traces and time course of IPSC suppression in a representative experiment in which TBF was delivered before E2. TBF occluded E2-induced IPSC suppression. $\boldsymbol{F}$, Group IPSC amplitude data for all TBF-responsive experiments $(n=6)$. $\boldsymbol{G}$, Group PPR data for the same cells as in $\boldsymbol{F} ;{ }^{* *} p<0.01$, paired $t$ test. $\boldsymbol{H}$, Group IPSC amplitude data for TBF- and E2-nonresponsive experiments $(n=7)$. Not shown are two cells that failed to respond to TBF but did respond to E2 (see Results). Calibration: $A, 50$ pA, 25 ms (also applies to $E$ ).

mGluR signaling leading to the mobilization of eCBs to suppress GABA release at a subset of inhibitory synapses. We next investigated what signaling downstream of group I mGluRs is required for E2-induced IPSC suppression.

\section{E2-induced suppression of inhibition requires}

phospholipase C

Group I mGluRs are $\mathrm{G} \alpha_{\mathrm{q}}$ coupled and lead to activation of phospholipase C (PLC), which is required for synaptically evoked mGluR-dependent iLTD (Chevaleyre and Castillo, 2003; Hashimotodani et al., 2005). We tested whether PLC is required 
A
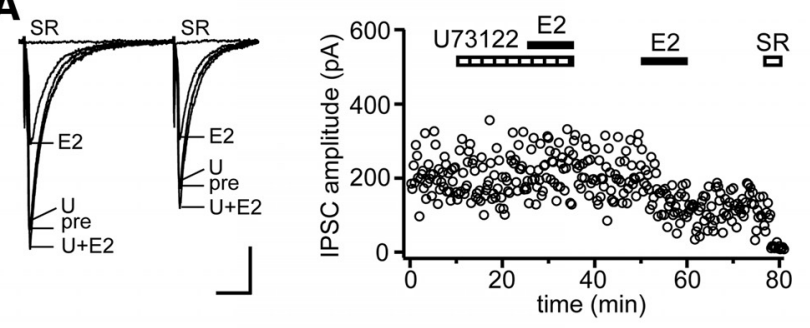

B

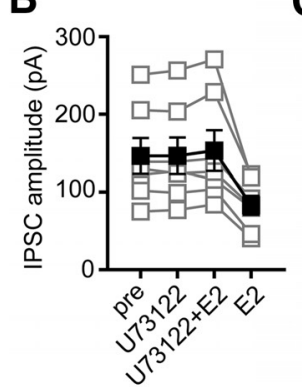

c

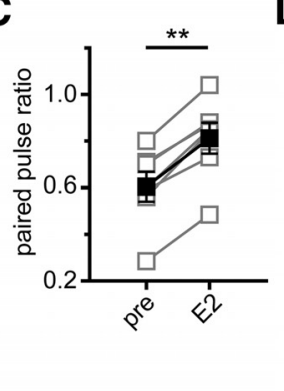

D

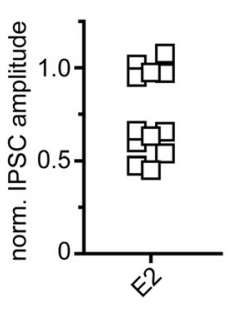

E
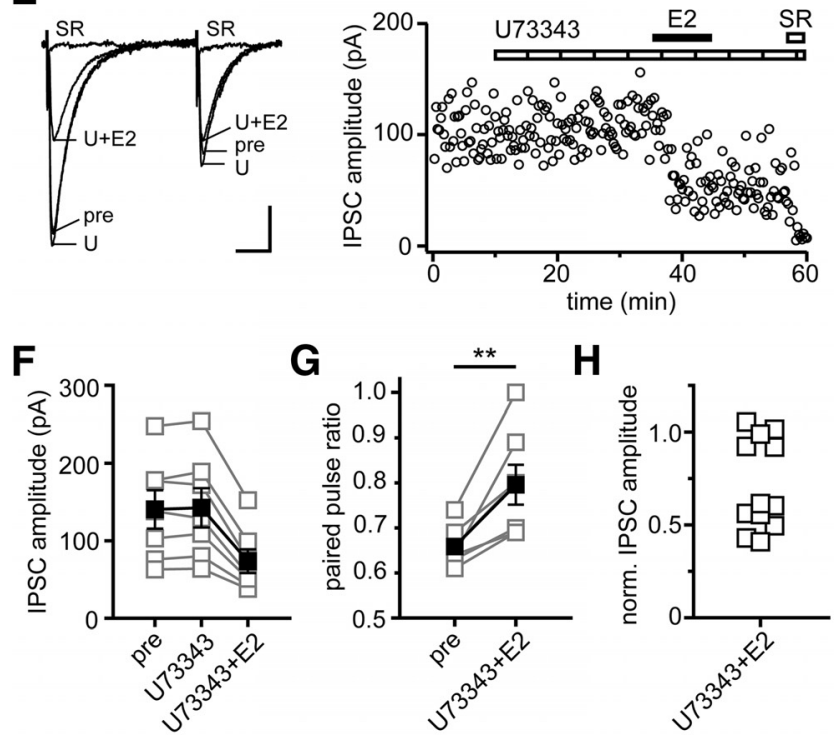

Figure 3. E2-induced suppression of inhibition requires PLC. A, Individual traces and time course of IPSC suppression in a representative experiment in which E2 (100 nM) was applied first in the presence of U73122 (U; PLC inhibitor, $10 \mu \mathrm{m}$ ) and then again after U73122 washout to confirm E2 responsiveness of IPSCs. U73122 blocked E2-induced IPSC suppression. Each point in the time course is an individual sweep, and SR 95531 (SR; $2 \mu \mathrm{m}$ ) applied at the end of the experiment blocked IPSCs (also in $\boldsymbol{E}$ ). B, Group IPSC amplitude data for experiments with E2responsive IPSCs $(n=7)$. Connected open symbols are individual cells; filled symbols are mean \pm SEM for all cells (also in $\boldsymbol{C}, \boldsymbol{F}, \boldsymbol{G}$ ). $\boldsymbol{C}$, Group PPR data for the same cells as in $\boldsymbol{B}$; ${ }^{* *} p<$ 0.01 , paired $t$ test. $\boldsymbol{D}$, Normalized IPSC amplitude for E2-responsive ( $n=7$, same as in $\boldsymbol{B}$ and $\boldsymbol{C})$ and E2-nonresponsive $(n=5)$ experiments. $\boldsymbol{E}$, Individual traces and time course of IPSC suppression in a representative experiment in which E2 was applied in the presence of U73343 (an inactive analog of U73122, $10 \mu \mathrm{M}$ ). E2 decreased IPSC amplitude in the presence of U73343. $\boldsymbol{F}$, Group IPSC amplitude data for all E2-responsive experiments $(n=7)$. $\mathbf{G}$, Group PPR data for the same cells as in $\boldsymbol{F}_{;}{ }^{* *} p<0.01$, paired $t$ test. $\boldsymbol{H}$, Normalized IPSC amplitude for E2-responsive ( $n=7$, same as in $\boldsymbol{F}$ and $\boldsymbol{G}$ ) and E2-nonresponsive $(n=5)$ experiments in the presence of U73343. Calibration: $\boldsymbol{A}, 50 \mathrm{pA}, 25 \mathrm{~ms} ; \boldsymbol{E}, 25 \mathrm{pA}, 25 \mathrm{~ms}$.

for E2-induced suppression of IPSCs by applying E2 (100 nM) in the presence of the PLC inhibitor U73122 or its inactive analog U73343 (both $10 \mu \mathrm{M}$ ). Because $\sim 45 \%$ of recordings are not responsive to E2, it was necessary to apply E2 alone after U73122 washout to confirm E2 responsiveness of IPSCs in each experiment (Fig. 3A). In 7 of 12 recordings (58\%), E2 had no effect on
IPSCs in the presence of U73122 (4 $\pm 3 \%)$ but decreased IPSC amplitude by $43 \pm 3 \%$ (Fig. $3 B)$ and increased PPR $(p<0.01$; Fig. $3 C$ ) after U73122 washout. The remaining five recordings with U73122 were not responsive to E2 (2 $\pm 4 \%$ change in IPSC amplitude; Fig. 3D). As expected, the inactive analog U73343 had no effect on IPSCs on its own $(2 \pm 2 \%)$ and failed to block E2-induced IPSC suppression (Fig. $3 E$ ) or the increase in PPR when applied in combination with E2. In 7 of 12 recordings with U73343 (58\%), E2 decreased IPSC amplitude by $48 \pm 3 \%$ (Fig. $3 F)$ and increased PPR $(p<0.01$; Fig. $3 G)$. The remaining five recordings in U73343 showed no response to E2 (Fig. $2 H$ ). These experiments demonstrated that PLC activation is required for E2-induced suppression of inhibition.

Sex difference in acute $\mathrm{E} 2$ regulation of intracellular $\mathrm{IP}_{3}$ levels We next addressed what signaling downstream of PLC is activated by $\mathrm{E} 2$ and whether this differs between males and females. Activation of PLC cleaves phosphatidylinositol 4,5-bisphosphate into diaceylglycerol (DAG) and $\mathrm{IP}_{3}$. DAG is a precursor of one principal eCB, 2-AG, which is a product of DAG lipase; however, E2-induced IPSC suppression is unaffected when 2-AG synthesis is blocked by a DAG lipase inhibitor (Huang and Woolley, 2012). Therefore, we focused on the alternative product of PLC activity, $\mathrm{IP}_{3}$, which binds to the $\mathrm{IP}_{3} \mathrm{R}$ to stimulate release of $\mathrm{Ca}^{2+}$ from intracellular stores (Furuichi et al., 1989) and can also stimulate eCB synthesis (Di Marzo et al., 1994; Fino et al., 2010).

We used a fluorescence polarization assay (Jin et al., 2013) to measure $\mathrm{IP}_{3}$ levels in hippocampal slices. As a positive control, we first tested how DHPG affects $\mathrm{IP}_{3}$ levels. Hippocampal slices were prepared from male and female rats and treated with vehicle or DHPG $(100 \mu \mathrm{M})$ for $0,5,10,15,20,30$, or $60 \mathrm{~s}$. As expected (Nakamura et al., 2000), DHPG induced a robust, transient increase in $\mathrm{IP}_{3}$. At elevated temperature $\left(34^{\circ} \mathrm{C}, n=3\right.$ independent experiments), the DHPG-induced increase in $\mathrm{IP}_{3}$ was essentially identical in males (9.7-fold; Fig. 4A) and females (9.8-fold; Fig. $4 B$ ), in both cases peaking at $15 \mathrm{~s}$ and returning to baseline by $30 \mathrm{~s}$; at room temperature ( $n=2$ independent experiments), the increase was similar in magnitude (9.5-fold for both sexes) but peaked later, at $20 \mathrm{~s}$ (data not shown). There were no sex differences in basal $\mathrm{IP}_{3}$ levels (males, $2.4 \pm 0.2 \mathrm{nM}$; females, $2.8 \pm 0.02$ $\mathrm{nM} ; p=0.172$ ) or in peak levels after DHPG stimulation (males, $23.2 \pm 2.5 \mathrm{~nm}$; females, $27.5 \pm 1.4 \mathrm{nM} ; p=0.818)$.

$\mathrm{E} 2$ also increased $\mathrm{IP}_{3}$ levels, but in contrast to experiments with DHPG, there was a clear sex difference. Based on pilot experiments indicating that the E2-induced increase in $\mathrm{IP}_{3}$ was slower than with DHPG, we tested E2 $\left(100 \mathrm{nM}, 34^{\circ} \mathrm{C}\right)$ at $0,10,15,30,60$, or $90 \mathrm{~s}(n=$ 3 independent experiments). This showed that $\mathrm{E} 2$ increased $\mathrm{IP}_{3}$ levels in both sexes but to a much greater extent in females (7.3-fold) than males (2.6-fold; Fig. 4C). In both sexes, E2-induced $\mathrm{IP}_{3}$ peaked at $30 \mathrm{~s}$ and returned to baseline by $60 \mathrm{~s}$. As with DHPG experiments, there was no sex difference in basal $\mathrm{IP}_{3}$ levels (males, $3.8 \pm 0.3 \mathrm{nM}$; females, $3.0 \pm 0.09 \mathrm{~nm} ; p=0.522$ ). However, $\mathrm{E} 2$ increased $\mathrm{IP}_{3}$ levels to $21.9 \pm 0.6 \mathrm{~nm}$ in females but only $9.7 \pm 0.9 \mathrm{nM}$ in males. Two-way ANOVA with repeated measures confirmed significant effects of treatment $\left(F_{(1,8)}=426.6, p<0.001\right)$, $\operatorname{sex}\left(F_{(1,8)}=222.1, p<0.001\right)$, and a treatment $\times$ sex interaction $\left(F_{(1,8)}=98.7, p<0.001\right)$. Next, because the E2-induced IPSC suppression that occurs in females is blocked by either the mGluR1 antagonist JNJ 16259685 or the mixed mGluR1/5 antagonist CPCCOEt but not by the mGluR5 antagonist MPEP (Huang and Woolley, 2012), we tested whether JNJ 16259685 also inhibited $\mathrm{E} 2$-induced $\mathrm{IP}_{3}$ generation in females. Slices were pretreated with JNJ $16259685(0.2 \mu \mathrm{M})$ or vehicle for $15 \mathrm{~min}$ and then exposed to vehicle or $\mathrm{E} 2$ for $0,10,15,30,60$, or $90 \mathrm{~s}$ ( $n=2$ independent 
A
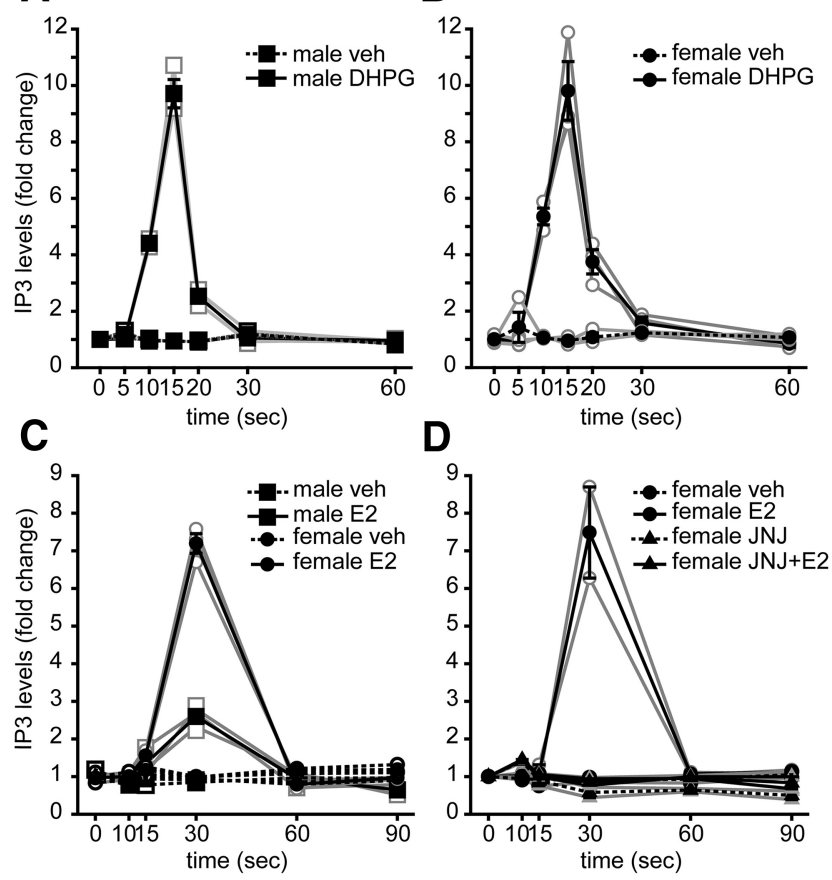

Figure 4. Sex difference in E2-induced generation of IP3. $A$, Fold change in intracellular $I_{3}$ levels measured in hippocampal slices from male rats treated with vehicle (veh) or DHPG (100 $\mu \mathrm{M})$ for $0,5,10,15,20,30$, or $60 \mathrm{~s}$. Connected open symbols are independent experiments $(n=$ 3); filled symbols are mean \pm SEM for all experiments (also in $\boldsymbol{B}-\boldsymbol{D}$ ). DHPG increased $\mathrm{IP}_{3}$ levels by 9.7 -fold in males peaking at $15 \mathrm{~s}$ and returning to baseline by $30 \mathrm{~s}$. B. Fold change in intracellular $\mathrm{P}_{3}$ levels measured in hippocampal slices from female rats treated exactly as in $\boldsymbol{A}$ $(n=3)$. Similar to males, DHPG increased $\mathrm{IP}_{3}$ levels by 9.8 -fold in females, peaking at $15 \mathrm{~s}$ and returning to baseline by $30 \mathrm{~s}$. C, Fold change in intracellular $I_{3}$ levels measured in hippocampal slices from male and female rats treated with vehicle or E2 (100 nm) for $0,10,15,30,60$, or $90 \mathrm{~s}$ ( $n=3$ in each sex). E2 increased IP $P_{3}$ levels in both sexes but to a much greater extent in females (7.3-fold) than males (2.6-fold). Two-way ANOVA with repeated measures showed significant effects of treatment $(p<0.001)$, sex $(p<0.001)$, and a treatment $\times$ sex interaction $(p<$ 0.001). $\boldsymbol{D}$, Fold change in intracellular $I P_{3}$ levels measured in hippocampal slices from female rats pretreated with vehicle or JNJ 16259685 (JNJ; mGluR1 antagonist, $0.2 \mu \mathrm{M}$ ) each followed by the addition of vehicle or E2 (100 nM) for $0,10,15,30,60$, or $90 \mathrm{~s}(n=2)$. JNJ 16259685 blocked the E2-induced increase in $\mathbb{P}_{3}(p<0.05$ one-way repeated-measures ANOVA, followed by Tukey's post hoc test).

experiments). This showed that JNJ 16259685 completely blocked the E2-induced increase in $\mathrm{IP}_{3}$ (Fig. $4 D ; F_{(3,7)}=29.6, p<0.05$, one-way repeated-measures ANOVA, followed by Tukey's post hoc test).

Together, these experiments demonstrated that E2 acutely increases $\mathrm{IP}_{3}$ levels to a significantly greater extent in females than males and that this effect in females requires mGluR1. That DHPG produced nearly identical increases in $\mathrm{IP}_{3}$ in both sexes indicates that mGluR to PLC signaling itself does not differ between the sexes.

\section{$\mathrm{E} 2$ acutely promotes $\mathrm{ER} \boldsymbol{\alpha}-\mathrm{mGluR} 1 \mathrm{a}$ interaction in females but not males}

As noted previously, E2-induced suppression of inhibition involves $\mathrm{ER} \alpha$. To investigate whether the sex specificity of E2-induced IPSC suppression arises upstream of mGluR-PLC signaling, we used co-IP to test for E2 regulation of an interaction between ER $\alpha$ and mGluR1. We prepared hippocampal slices from adult male and female rats and treated half the slices from each animal with E2 (100 $\mathrm{nM}$ ) or vehicle for $10 \mathrm{~min}$ to parallel electrophysiology experiments. We then prepared membrane fractions from these slices and subjected them to IP using anti-mGluR1a. Input and IP samples from males and females were run together on the same gel, along with a no-lysate control, and Western blots were probed for ER $\alpha$, PSD-95 (as a negative control), or mGluRla (Fig. 5A). Quantification of five independent runs of this experiment showed that E2 increased the levels of $\mathrm{ER} \alpha$ associated with mGluRla in females ( $p<0.05)$, but not in males, without affecting mGluRla itself in either sex (Fig. $5 B$ ). Comparing the ratio of $\mathrm{ER} \alpha$ to mGluRla within each experiment (Fig. $5 C$ ) confirmed that E2 increased the ER $\alpha / \mathrm{mGluR} 1$ a ratio in females in all five experiments $(p<0.05)$, with no effect in males. PSD-95 showed no interaction with mGluRla (Fig. 5A), confirming the specificity of the co-IP procedure. The no-lysate control was used to identify anti-mGluR1a antibody chains that were also eluted and detected by Western blot in the IP samples. Together, these experiments demonstrated that E2 promotes a physical interaction between ER $\alpha$ and mGluR1a in the female, but not male, hippocampus.

Although multiple studies point to $\mathrm{ER} \alpha-\mathrm{mGluR} 1$ interaction as being important in mediating acute E2 actions (Dewing et al., 2007; Huang and Woolley, 2012; Boulware et al., 2013), other studies indicate that mGluR5 plays the predominant role in eCB-mediated retrograde suppression of IPSCs in the hippocampus (Katona et al., 2006; Tanimura et al., 2010). Thus, we used the same co-IP approach in slices from females to investigate $\mathrm{ER} \alpha$ interaction with mGluR5. However, in three independent experiments, we detected no interaction between ER $\alpha$ and mGluR5 and no effect of E2 (Fig. 5D). This lack of ER $\alpha$ interaction with mGluR5 corroborates electrophysiological evidence that mGluR1 and not mGluR5 mediates E2induced suppression of inhibition.

Extranuclear ER $\alpha$ has been reported presynaptically and postsynaptically in the CA1 region, in both pyramidal cells and interneurons (Milner et al., 2001; Hart et al., 2007). To investigate whether $\mathrm{ER} \alpha$ detected in co-IP analysis of membrane fractions could be associated with CA1 pyramidal cell somatic plasma membranes, we evaluated ER $\alpha$ immunolabeling in $30 \mathrm{CA} 1$ pyramidal cell somata, 10 from each of three ovariectomized female rats. This showed patches of ER $\alpha$ labeling along the inner side of the somatic plasma membrane (Fig. $5 E$ ), often associated with the endoplasmic reticulum. $\mathrm{ER} \alpha$ labeling was also observed associated with the Golgi apparatus and in a subset of axonal boutons, as has been reported previously (Hart et al., 2007). Thus, ER $\alpha$ detected in co-IP experiments could reflect ER $\alpha$ localized at the somatic plasma membrane of CA1 pyramidal cells, at least in part, but could also include other membrane compartments as well.

\section{$\mathrm{E} 2$ acutely promotes $\mathrm{mGluR} 1 \mathrm{a}-\mathrm{IP}_{3} \mathrm{R}$ interaction in females but not males}

Group I mGluRs are physically coupled to $\mathrm{IP}_{3} \mathrm{Rs}$ and regulate $\mathrm{Ca}^{2+}$ signaling in CA1 pyramidal cells (El-Hassar et al., 2011). Our findings that $\mathrm{E} 2$ acutely stimulates $\mathrm{IP}_{3}$ synthesis more robustly in females (7.3-fold) than males (2.6-fold) suggested that E2 might modulate an mGluR1- $\mathrm{IP}_{3} \mathrm{R}$ interaction differentially in males and females. To investigate this, we used co-IP in hippocampal slices to test whether $\mathrm{E} 2$ influences interaction between $\mathrm{mGluR} 1$ and $\mathrm{IP}_{3} \mathrm{R}$, using the same approach as in experiments investigating $\mathrm{ER} \alpha-\mathrm{mGluR} 1$ interaction (Fig. 5). Hippocampal slices from males and females were treated for 10 min with E2 (100 nM) or vehicle, and then membrane fractions were subjected to IP using anti-mGluRla. Samples from each experiment were run together on the same gel, and Western blots were probed for $\mathrm{IP}_{3} \mathrm{R}$ and mGluR1 (Fig. $6 \mathrm{~A}$ ); in a subset of experiments, we also probed for Homer-1b/c (see below). Quantification of six independent experiments showed that E2 increased the levels of $\mathrm{IP}_{3} \mathrm{R}$ associated with mGluR1 in females $(p<0.01)$, but not in males, without affecting mGluR1 in either sex (Fig. 6B). Comparing $\mathrm{IP}_{3} \mathrm{R}$ to mGluR1 ratios (Fig. $6 \mathrm{C}$ ) confirmed that, in all six experi- 


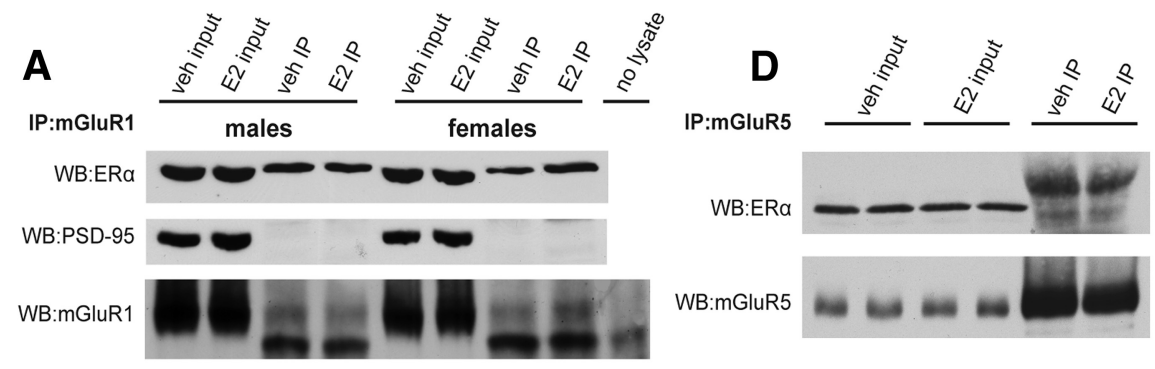

investigated whether the $\mathrm{IP}_{3} \mathrm{R}$ is required for E2-induced suppression of IPSCs in females. The synthesis of eCBs is known to be $\mathrm{Ca}^{2+}$ dependent (Di Marzo et al., 1994), and $\mathrm{Ca}^{2+}$ release from intracellular stores, such as through the $\mathrm{IP}_{3} \mathrm{R}$, regulates eCB synthesis (Hashimotodani et al., 2007).

We tested whether the $\mathrm{IP}_{3} \mathrm{R}$ inhibitor
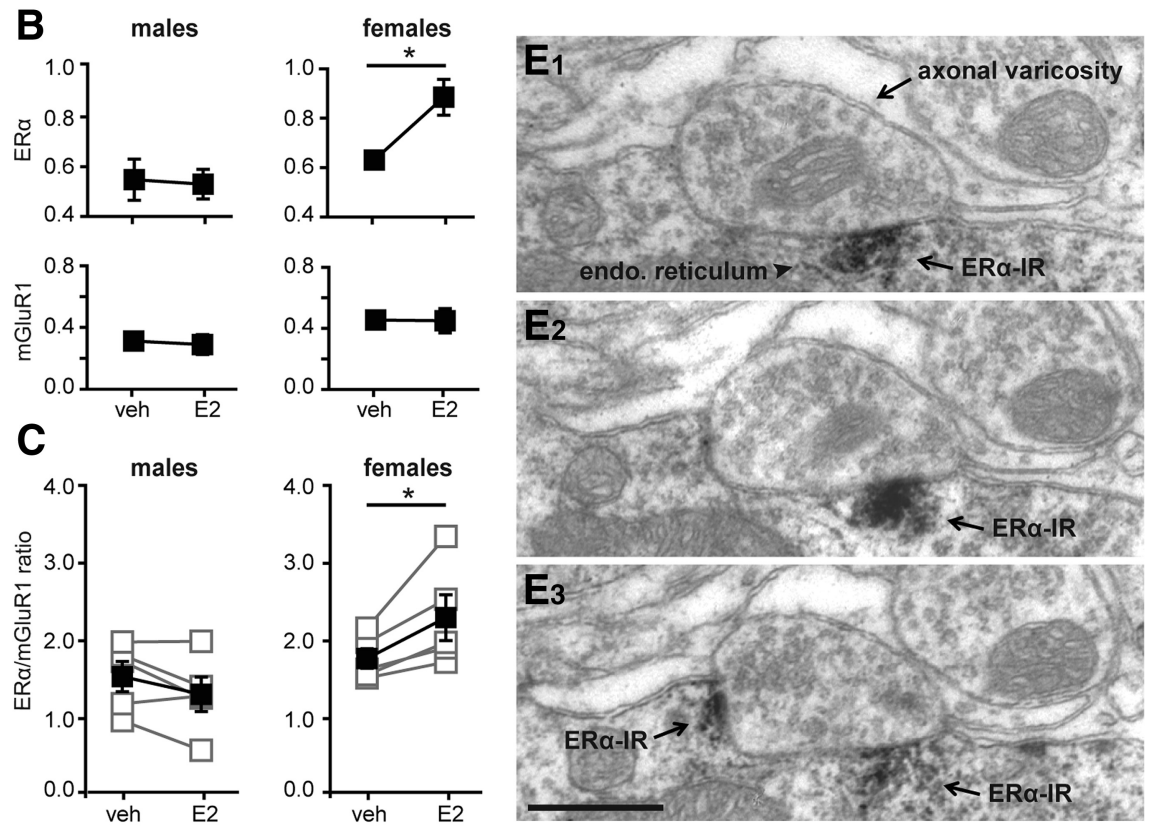

Figure 5. E2 acutely promotes $\mathrm{ER} \alpha-\mathrm{mGluR} 1$ interaction in females but not males. $\boldsymbol{A}$, Hippocampal slices from male and female rats were treated with either $\mathrm{E} 2(100 \mathrm{~nm})$ or vehicle (veh) for $10 \mathrm{~min}$. Membrane fractions were prepared from these slices and subjected to IP using anti-mGluR1a. Representative Western blots (WB) of input and IP samples from males and females on the same gel including a no-lysate control are shown. Blots were probed for ER $\alpha$, PSD-95 (negative control), and mGluR1a. B, Mean \pm SEM of ER $\alpha$ and mGluR1 levels in males and females ( $n=5$ independent experiments). E2 increased the levels of ER $\alpha$ associated with mGluR1a in females, but not in males, without affecting mGluR1a levels in either sex; ${ }^{*} p<0.05$, Student's $t$ test. $\boldsymbol{C}$, $\mathrm{ER} \alpha / \mathrm{mGluR} 1$ ratio for the same five experiments as in $\boldsymbol{B}$ (see Materials and Methods). Connected open symbols are individual experiments; filled symbols are mean \pm SEM for all experiments. E2 increased ER $\alpha / m G l u R 1$ ratio in females with no effect in males; ${ }^{*} p<0.05$, paired $t$ test. $\boldsymbol{D}$, Hippocampal slices from female rats were treated either with E2 (100 nm) or vehicle for $10 \mathrm{~min}$. Membrane fractions were prepared from these slices and subjected to IP using anti-mGluR5. Representative Western blots of input and IP samples probed for ER $\alpha$ and mGluR5 are shown. No interaction was detected between ER $\alpha$ and mGluR5 in either of the IP samples. $\boldsymbol{E}$, Representative electron micrographs of three serial sections (E1-E3) showing ER $\alpha$ immunoreactivity (ER $\alpha$-IR) located in patches along the CA1 pyramidal cell somatic plasma membrane. Note endoplasmic reticulum associated with ER $\alpha-I R$ and an axonal varicosity apposed to the soma near $E R \alpha-I R$. Scale bar: $E 3,500 \mathrm{~nm}$ (applies to all panels).

ments, $\mathrm{E} 2$ increased the $\mathrm{IP}_{3} \mathrm{R} / \mathrm{mGluR} 1$ ratio in females $(p<0.01)$, with no effect in males.

Studies in multiple cell types have demonstrated that Homer proteins associate with mGluR1 in complex with the $\mathrm{IP}_{3} \mathrm{R}$ (Tu et al., 1998; Hu et al., 2012). In particular, long-form Homers, such as Homer-1b/c, tether mGluRs in close proximity to $\mathrm{IP}_{3} \mathrm{Rs}$ and promote $\mathrm{IP}_{3} \mathrm{R}$ signaling (Kammermeier, 2008; Hayashi et al., 2009). Thus, in four experiments, we also probed blots for Homer-1b/c. However, as for the $\mathrm{IP}_{3} \mathrm{R}$, we found no sex differences in vehicletreated slices and that E2 increased the Homer- $1 \mathrm{~b} / \mathrm{c} / \mathrm{mGluR} 1$ ratio in females $38 \pm 9 \%$ (range $13-56 \%, p=0.05$ ), with no effect in males $(0.3 \pm 4 \%$; range $-12-7 \%$; data not shown).

\section{E2-induced suppression of inhibition requires the $\mathrm{IP}_{3} \mathrm{R}$}

Having shown that $\mathrm{ER} \alpha$, mGluR 1 , and $\mathrm{IP}_{3} \mathrm{R}$ form a complex that is sensitive to E2 specifically in females and that E2 acutely increases $\mathrm{IP}_{3}$ levels to a greater extent in females than males, we next
Xestospongin C $(2 \mu \mathrm{M})$ blocks E2induced suppression of inhibition by applying E2 (100 nM) in the presence of Xest and then again after Xest washout to confirm E2 responsiveness of IPSCs (Fig. 6D). In four of seven recordings (57\%), blocking the $\mathrm{IP}_{3} \mathrm{R}$ with Xest itself increased IPSC amplitude by $107 \pm 20 \%$, without affecting PPR, consistent with previous reports that Xest increases postsynaptic sensitivity to GABA (Yu et al., 2006). Importantly, E2 applied in the presence of Xest had no effect on IPSC amplitude $(-1 \pm 3 \%)$ yet decreased IPSC amplitude by $43 \pm 3 \%$ when applied a second time after Xest washout (Fig. 6E). In parallel, the second application of E2 increased PPR from $0.66 \pm 0.02$ to $0.81 \pm 0.05(p<$ $0.05)$. The three cells that did not respond to Xest ( $7 \pm 0.7 \%$ change in IPSC amplitude) also showed no response to E2 (4 \pm $2 \%$ change in IPSC amplitude; data not shown). Thus, the $\mathrm{IP}_{3} \mathrm{R}$ is required for $\mathrm{E} 2$ induced IPSC suppression.

\section{A subset of CA1 pyramidal cells expresses mGluR1a mRNA}

Our results so far indicated that E2induced suppression of inhibition occurs through ER $\alpha$-mGluR1-PLC-IP3-IP ${ }_{3} \mathrm{R}$ signaling. The simplest model to explain these results posits that this pathway is activated in postsynaptic CA1 pyramidal cells to mobilize eCBs from these cells. The presence of $\operatorname{ER} \alpha$ at CA1 pyramidal cell somatic membranes is consistent with this idea. However, one caveat is that previous immunostaining (Baude et al., 1993) and in situ hybridization (Shigemoto et al., 1992) studies show little to no mGluR1 expression in CA1 pyramidal cells. Thus, either the pathway we have described is active in some other cell type leading to suppression of inhibitory synapses on CA1 pyramidal cells or CA1 pyramidal cells express mGluR1 that is not detected by antibody staining or in situ hybridization. To investigate this further, we used single-cell nested PCR to test for mGluRla mRNA expression in individual CA1 pyramidal cells from ovariectomized female rats. For the first RT-PCR step in this procedure, primers were designed to target three distinct regions in the mGluRla mRNA sequence: (1) the N-terminal region common in all splice variants (Kosinski et al., 1998); (2) the splicing region; and (3) the C-terminal region that contains the recognition site for the mGluRla antibody used in co-IP experiments. In the second realtime PCR step, five separate pairs of nested PCR primers were designed to amplify fragments of various lengths within the first 
PCR amplicons (Fig. 7A; Table 1). To aid in identifying CA1 pyramidal cells, we included nested PCR primers for the following: (1) two housekeeping genes, glyceraldehyde 3-phosphate dehydrogenase (GAPDH) and hypoxanthine phosphoribosyltransferase (HPRT); (2) three markers for GABAergic neurons, neuregulin-1 receptor ERBB4, vesicular GABA transporter (vGAT), and glutamic acid decarboxylase 2 (GAD65); and (3) glial fibrillary acidic protein (GFAP) to identify astrocytes. We also tested for mGluR5. Specificity tests confirmed that each primer generated a unique amplicon of the appropriate size (Fig. 7B). To consider cells to be CA1 pyramidal cells, we required them to be positive for both housekeeping genes and negative for all three GABAergic markers as well as GFAP. To identify GABAergic neurons, we required cells to be positive for both housekeeping genes and at least two of three GABAergic markers and negative for GFAP.

Based on these requirements, we identified 28 CA1 pyramidal neurons from eight female rats and eight GABAergic neurons from five of the same pool of rats (Fig. $7 C$ ). Of the 28 putative CA1 pyramidal cells, $14(50 \%)$ showed mGluR1a expression, evidenced by detection of all five targeted mGluR1a fragments. A greater fraction of pyramidal cells, 24 of 28 (86\%), expressed mGluR5. Four mGluR1a-positive cells lacked mGluR5, 14 mGluR5-positive cells lacked mGluR1a, and 10 cells expressed both mGluR1a and mGluR5. Of the eight putative GABAergic neurons we identified, five expressed mGluRla, four expressed mGluR5, and two cells expressed both (Fig. 7C). Together, these results indicated that as many as $50 \%$ of CA1 pyramidal cells express mGluR1a mRNA, making it possible that E2 acts directly on these cells to activate mGluR1-dependent signaling leading to IPSC suppression.
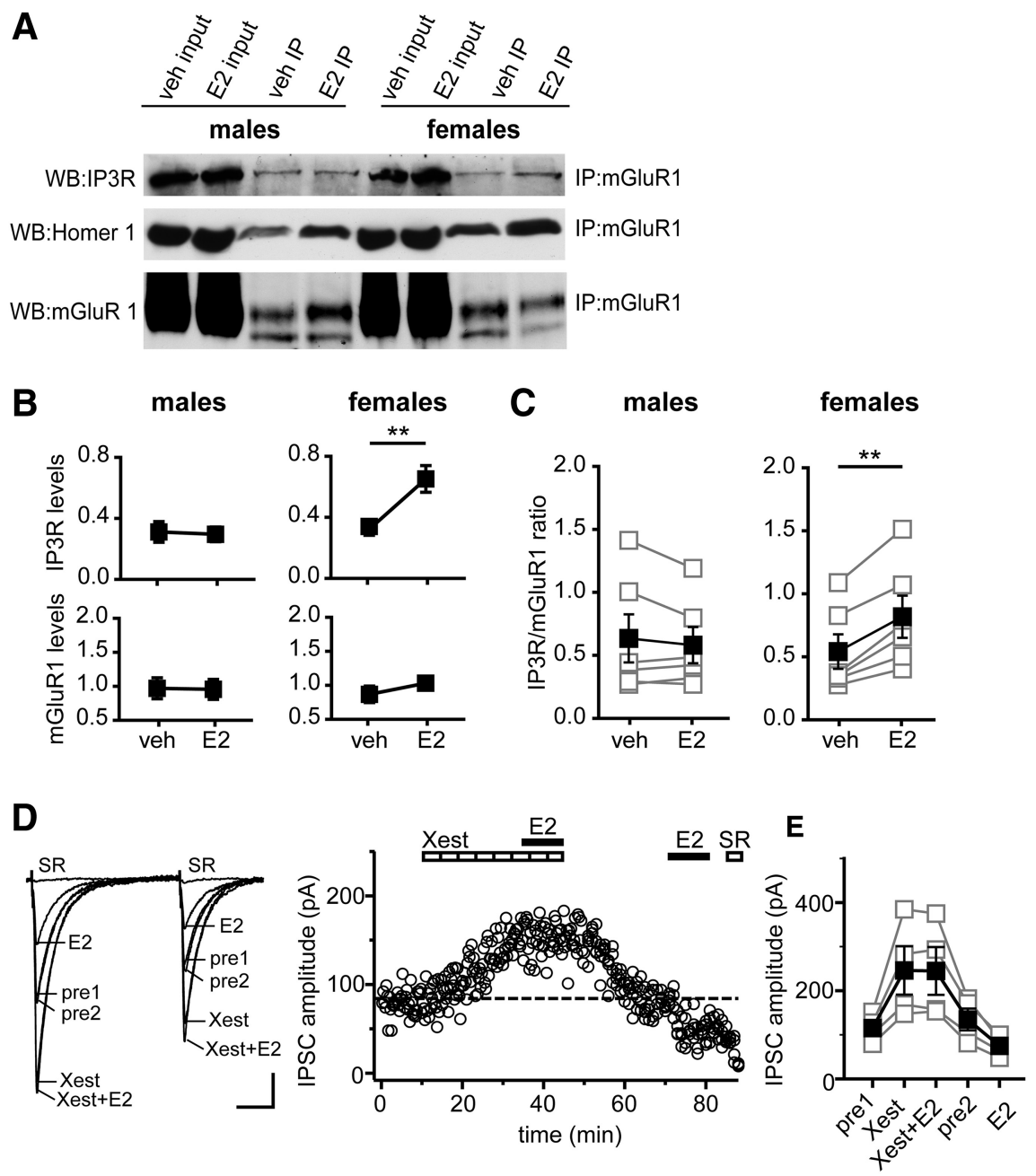

Figure 6. E2 acutely promotes $m G l u R 1-I P_{3}$ R interaction in females but not males. $A$, Hippocampal slices from male and female rats were treated either with E2 (100 nm) or vehicle (veh) for $10 \mathrm{~min}$. Membrane fractions were prepared from these slices and subjected to IP using anti-mGluR1a. Representative Western blots (WB) of input and IP samples from males and females on the same gel are shown. The blots were probed for $I P_{3} R$, Homer- $1 b / c$ and $m G l u R 1$. $B$, Mean $\pm S E M$ of $I P{ }_{3} R$ and $m G$ luR1 levels in males and females ( $n=6$ independent experiments). E2 increased the levels of $I P_{3} R$ associated with mGluR1a in females, but not in males, without affecting mGluR1a levels in either sex; ${ }^{* *} p<0.01$, Student's $t$ test. $C, I_{3} R / m G l u R 1$ ratio for the same six experiments as in $\boldsymbol{B}$ (see Materials and Methods). Connected open symbols are individual experiments $(n=6)$; filled symbols are mean \pm SEM for all experiments. E2 increased the $I P_{3} R / m G l u R 1$ ratio in females with no effect in males; ${ }^{* *} p<0.01$, paired $t$ test. $D$, Individual traces and time course of IPSC suppression in a representative experiment in which E2 (100 nm) was applied first in the presence of Xest $\left(\mathbb{I P}_{3}\right.$ R inhibitor, $\left.2 \mu \mathrm{m}\right)$ and then again after Xest washout to confirm E2 responsiveness of IPSCs. Dotted line shows average IPSC amplitude during 2 min before the second E2 application. Xest blocked E2-induced IPSC suppression. Each point in the time course is an individual sweep, and SR 95531 (SR; $2 \mu \mathrm{m}$ ) applied at the end of the experiment blocked IPSCs. E, Group IPSC amplitude data for all experiments with E2-responsive IPSCs $(n=4)$. Connected open symbols are individual cells; filled symbols are mean \pm SEM for all cells. Calibration: $D, 25$ pA, 25 ms.

\section{E2-induced suppression of inhibition is blocked by postsynaptic eCB transporter inhibition}

We next tested whether the $\mathrm{eCB}(\mathrm{s})$ that underlie E2-induced IPSC suppression are derived from CA1 pyramidal cells. eCB transport from postsynaptic cells can be inhibited by including AM404 $(2 \mu \mathrm{M})$ in the recording pipette (Ronesi et al., 2004). Of 19 experiments with AM404-loaded pipettes (Fig. 8A), E2 decreased IPSC amplitude in only three cases (16\%), which is a much lower response rate than the 29 of 52 (56\%) experiments with standard internal solution in the current study (Fig. $8 B ; \chi^{2}$ $=8.9, p<0.01)$. This strongly suggests that the eCB $(\mathrm{s})$ that mediate E2-induced IPSC suppression are released directly from postsynaptic CA1 pyramidal cells. We also tested DSI in experiments with AM404 and found no effect on DSI (Fig. 8C), indi- cating that 2-AG-dependent modulation of inhibition was intact even when E2-induced suppression of inhibition was blocked. This is consistent with our previous findings that inhibition of 2-AG synthesis or breakdown has no effect on E2-induced suppression of inhibition (Huang and Woolley, 2012).

The evidence against 2-AG as being involved in E2-induced suppression of inhibition points to AEA as the eCB most likely to mediate the effects of E2. AEA is synthesized via $\mathrm{Ca}^{2+}$-sensitive phosphodiesterase activity (Di Marzo et al., 1994), and mobilization of intracellular $\mathrm{Ca}^{2+}$ by the PLC/IP 3 pathway stimulates AEA synthesis in HEK-293 cells and sensory neurons (van der Stelt et al., 2005). Thus, activation of $\mathrm{PLC} / \mathrm{IP}_{3}$ signaling by E2 could stimulate AEA synthesis in the hippocampus. In support of this idea, E2-induced IPSC suppression is occluded by inhibition 

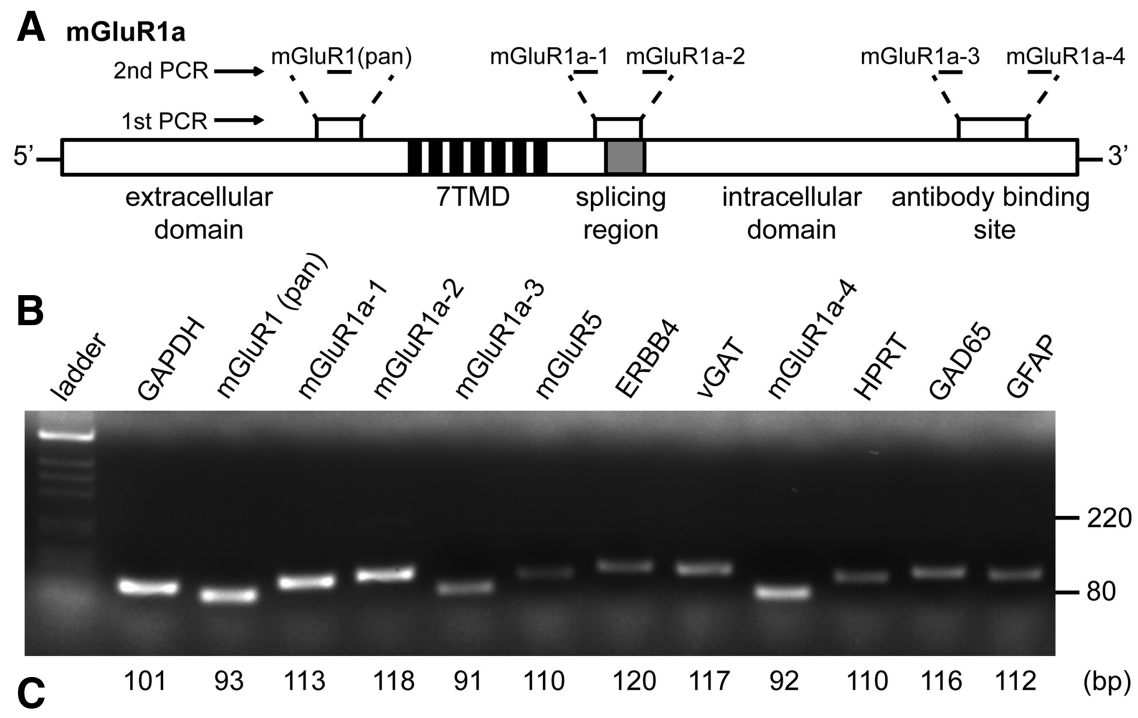

\begin{tabular}{|c|c|c|c|c|c|c|c|c|c|}
\hline \multicolumn{2}{|c|}{ Putative CA1 pyramidal cells } & GAPDH & HPRT & mGluR1 & mGluR5 & ERBB4 & vGAT & GAD65 & GFAP \\
\hline rats & cells & & & & & & & & \\
\hline \multirow{5}{*}{1} & 1 & + & + & + & + & - & - & - & - \\
\hline & 2 & + & + & + & + & - & - & - & - \\
\hline & 3 & + & + & - & + & - & - & - & - \\
\hline & 4 & + & + & + & + & - & - & - & - \\
\hline & 5 & + & + & + & - & - & - & - & - \\
\hline \multirow{2}{*}{2} & 6 & + & + & + & + & - & - & - & - \\
\hline & 7 & + & + & - & + & - & - & - & - \\
\hline \multirow{3}{*}{3} & 8 & + & + & + & + & - & - & - & - \\
\hline & 9 & + & + & - & + & - & - & - & - \\
\hline & 10 & + & + & + & - & - & - & - & - \\
\hline \multirow{2}{*}{4} & 11 & + & + & + & + & - & - & - & - \\
\hline & 12 & + & + & - & + & - & - & - & - \\
\hline \multirow{2}{*}{5} & 13 & + & + & + & - & - & - & - & - \\
\hline & 14 & + & + & - & + & - & - & - & - \\
\hline \multirow[b]{2}{*}{6} & 15 & + & + & + & + & - & - & - & - \\
\hline & 16 & + & + & - & + & - & - & - & - \\
\hline \multirow{5}{*}{7} & 17 & + & + & - & + & - & - & - & - \\
\hline & 18 & + & + & - & + & - & - & - & - \\
\hline & 19 & + & + & + & + & - & - & - & - \\
\hline & 20 & + & + & - & + & - & - & - & - \\
\hline & 21 & + & + & - & + & - & - & - & - \\
\hline \multirow{8}{*}{8} & 22 & + & + & - & + & - & - & - & - \\
\hline & 23 & + & + & - & + & - & - & - & - \\
\hline & 24 & + & + & + & - & - & - & - & - \\
\hline & 25 & + & + & + & + & - & - & - & - \\
\hline & 26 & + & + & - & + & - & - & - & - \\
\hline & 27 & + & + & - & + & - & - & - & - \\
\hline & 28 & + & + & + & + & - & - & - & - \\
\hline & total & 28 & 28 & 14 & 24 & 0 & 0 & 0 & 0 \\
\hline \multicolumn{10}{|c|}{ Putative CA1 GABAergic cells } \\
\hline \multirow{3}{*}{1} & 1 & + & + & + & - & - & + & + & - \\
\hline & 2 & + & + & - & + & + & + & + & - \\
\hline & 3 & + & + & - & - & - & + & + & - \\
\hline 3 & 4 & + & + & - & + & + & + & + & - \\
\hline 6 & 5 & + & + & + & + & + & + & + & - \\
\hline 7 & 6 & + & + & + & - & - & + & + & - \\
\hline \multirow{3}{*}{8} & 7 & + & + & + & - & - & + & + & - \\
\hline & 8 & + & + & + & + & + & + & + & - \\
\hline & total & 8 & 8 & 5 & 4 & 3 & 8 & 8 & 0 \\
\hline
\end{tabular}

Figure 7. A subset of CA1 pyramidal cells expresses mGluR1a mRNA. $A$, A schematic mGluR1a mRNA sequence showing three regions that were targeted in single-cell nested PCR experiments: the first region is located within the N-terminal extracellular domain common in all splice variants, the second region is located after the seven transmembrane domain (7TMD) and includes the splicing region, and the third region is located in the C-terminal domain that contains the recognition site for the mGluR1a antibody used in co-IP experiments. In the second real-time PCR step, five separate pairs of nested PCR primers targeted fragments of various lengths within the first PCR amplicons (mGluR1 pan, mGluR1a-1, -2, -3, -4). $\boldsymbol{B}$, Specificity of all primers was tested on whole hippocampal $\mathrm{mRNA}$ isolated from a female rat. Representative gel image showing unique amplicons of appropriate sizes for each gene tested. C, Single-cell nested PCR results showing mRNA expression profiles for all putative CA1 pyramidal neurons and GABAergic neurons derived from eight female rats. To be considered as a putative $C A 1$ pyramidal neuron, a cell was required to be positive for GAPDH and HPRT (housekeeping genes) and negative for ERBB4, VGAT, GAD65 (GABAergic markers), and GFAP (astrocyte marker). To be considered mGluR1a positive, a cell was required to be positive for all five mGluR1a fragments. Of 28 putative CA1 pyramidal neurons, 14 (50\%) were mGluR1a positive and 24 (86\%) were mGluR5 positive. of fatty acid amide hydrolase (FAAH), which degrades AEA, but not by inhibition of monoacylglycerol lipase, which degrades 2-AG (Huang and Woolley, 2012). To investigate a role for postsynaptic $\mathrm{Ca}^{2+}$ in E2-induced suppression of inhibition, we performed experiments with BAPTA $(20 \mathrm{~mm})$ in the recording pipette (Chevaleyre and Castillo, 2003; Younts et al., 2013; Fig. 8D). This showed that chelating postsynaptic $\mathrm{Ca}^{2+}$ strongly inhibited E2-induced IPSC suppression. Only 1 of 17 experiments (6\%) with BAPTA-loaded pipettes showed a decrease in IPSC amplitude of $>10 \%$ after E2 application (Fig. $8 E$ ), a much lower response rate than the $56 \%$ of $\mathrm{E} 2$-responsive experiments with standard internal solution (Fig. $8 F ; \chi^{2}=12.97, p<0.001$ ). In parallel, BAPTA also inhibited the E2induced increase in PPR $(0.7 \pm 0.01$ vs $0.7 \pm 0.02)$.

Together, these results corroborated previous evidence that an $\mathrm{ECB}$ other than 2-AG mediates E2-induced suppression of perisomatic inhibition in females and further indicate that this $\mathrm{eCB}$ is released from postsynaptic $\mathrm{CA} 1 \mathrm{py}-$ ramidal cells through a $\mathrm{Ca}^{2+}$ dependent process. AEA is the most likely candidate to mediate the actions of E2, although we cannot rule out the possibility that other FAAHsensitive lipids, such as oleamide or $\mathrm{N}$-palmitoylethanolamide, could be involved (Cravatt et al., 1996).

\section{Sex difference in tonic eCB signaling}

That E2-induced suppression of inhibition is sex-specific suggests that AEA signaling at inhibitory synapses in the hippocampus might differ between males and females. To investigate a sex difference independently of E2, we tested how inhibitory synapses in males and females respond to inhibition of FAAH. Previous studies using slices from male rats found no effect of FAAH inhibition on baseline IPSCs (Hájos et al., 2004; Kim and Alger, 2004), indicating no tonic AEA release under basal conditions. Consistent with this, we found that, in 17 recordings in males (Fig. $8 G$ ), the FAAH inhibitor URB597 $(1 \mu \mathrm{M})$ had no overall effect on IPSC amplitude ( $3 \pm 2 \%$ ), and only one cell showed a decrease of $>10 \%$. In contrast, in 10 of $18(55 \%)$ identical experiments in females (Fig. 8H), URB597 decreased IPSC amplitude by $43 \pm 4 \%$ (Fig. $8 I$ ) and increased PPR $(p<0.01 ;$ Fig. $8 J)$. In the other eight experiments with females, there was no effect of URB597 on IPSC amplitude $(0.7 \pm 2 \%)$ or PPR. There was no difference in initial PPR between URB597-responsive and -nonresponsive recordings $(0.67 \pm 0.04$ vs $0.69 \pm 0.03, p=0.712)$ in females. Figure 


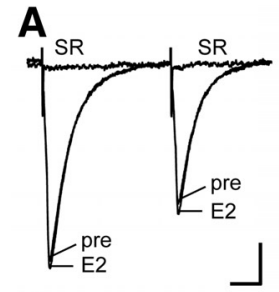

B

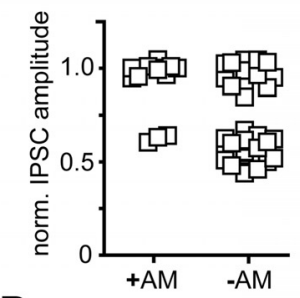

D

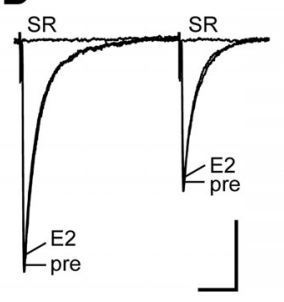

E
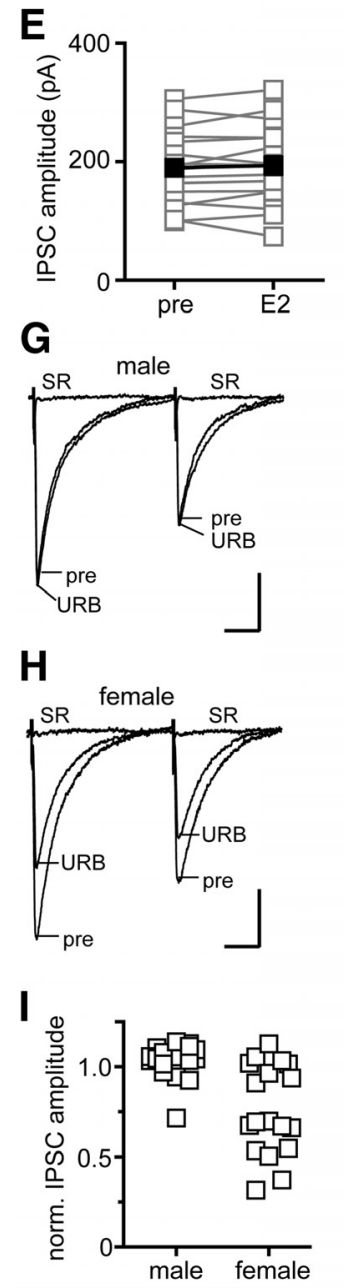
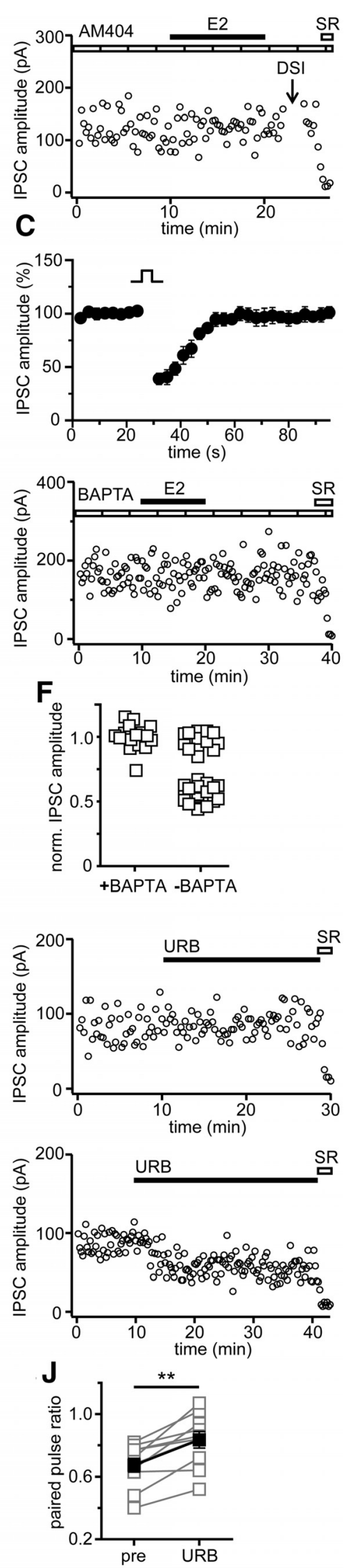

Figure 8. E2-induced suppression of inhibition is $\mathrm{Ca}^{2+}$ dependent and requires postsynaptic eCB release. $A$, Individual traces and time course of a representative experiment in which E2-induced suppression of inhibition was tested with AM404 (AM; eCB transporter inhibitor, 2

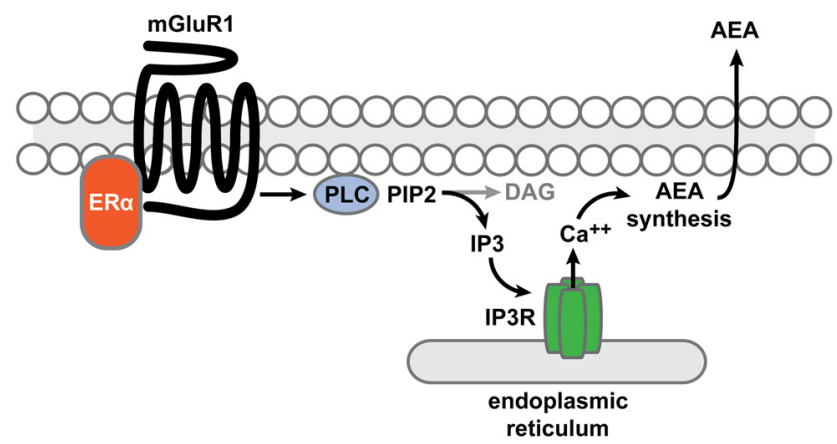

Figure 9. Model of intracellular signaling that underlies acute E2-induced suppression of inhibition. Our results support a model in which, in the female hippocampus, E2 acutely suppresses inhibition by promoting an interaction between membrane-associated ER $\alpha$ and mGluR1, which activates $P L C$ to generate $\mathrm{IP}_{3}$ and stimulate $\mathrm{Ca}^{2+}$ release via the $\mathrm{IP}_{3} \mathrm{R}$ located on the endoplasmic reticulum, leading to $\mathrm{Ca}^{2+}$-dependent AEA synthesis and mobilization from postsynaptic cells.

8I shows a comparison of URB597-induced changes in IPSC amplitude for all cells recorded from both sexes, demonstrating a significant sex difference in response rate $\left(\chi^{2}=10.01, p<0.01\right)$. The ability of URB597 alone to decrease IPSC amplitude and increase PPR in more than half of experiments in females indicates that a substantial fraction of inhibitory synapses in females is under tonic inhibition by a FAAH-sensitive $\mathrm{CB}$, likely $\mathrm{AEA}$, which is lacking in males. These results demonstrate that, even beyond sex differences in acute $\mathrm{E} 2$ modulation of inhibitory synapses, regulation of the $\mathrm{eCB}$ system in the hippocampus differs fundamentally between males and females.

\section{Discussion}

In the current study, we investigated molecular factors that underlie acute, sex-specific modulation of inhibitory synapses in the hippocampus by E2. Previous work showed that E2 modulation of inhibition depends on $\mathrm{ER} \alpha$, mGluR1, and $\mathrm{CB}_{1} \mathrm{Rs}$ (Huang and Woolley, 2012). Here, we demonstrate that this effect requires PLC, the $\mathrm{IP}_{3} \mathrm{R}$, and eCB mobilization from postsynaptic cells. We further show that mGluR1 forms a complex with $\mathrm{ER} \alpha$ and the

\footnotetext{
$\leftarrow$

$\mu \mathrm{m}$ ) applied postsynaptically via the recording pipette. Each point in the time course is an individual sweep, and SR 95531 (SR; $2 \mu \mathrm{M}$ ) applied at the end of the experiment blocked IPSCS (also in $\boldsymbol{D}, \boldsymbol{G}, \boldsymbol{H}$ ). E2-induced suppression of inhibition was rare in AM404-loaded cells. $\boldsymbol{B}$, Normalized IPSC amplitude for E2-responsive and -nonresponsive experiments with and without AM404 in the recording pipette. of 19 cells recorded with AM404, only three showed E2induced IPSC suppression compared with 29 of 52 cells recorded without AM404; $p<0.01, \chi^{2}$ test. C, DSI was normal in the same AM404-loaded cells as in $\boldsymbol{B}$, confirming that AM404 did not affect 2-AG-mediated modulation of inhibition. Points are mean \pm SEM for all experiments. $\boldsymbol{D}$ Individual traces and time course of a representative experiment in which BAPTA $\left(\mathrm{Ca}^{2+}\right.$ chelator, $20 \mathrm{~mm}$ ) was applied postsynaptically via the recording pipette. E, Group IPSC amplitude data for all experiments with BAPTA $(n=17)$. Connected open symbols are individual cells; filled symbols are mean \pm SEM for all cells. E2-induced suppression of inhibition was rare in BAPTAloaded cells. $\boldsymbol{F}$, Normalized IPSC amplitude for E2-responsive and -nonresponsive experiments with and without BAPTA in the recording pipette. Of 17 cells recorded with BAPTA, only one showed E2-induced IPSC suppression, compared with 29 of 52 cells recorded without BAPTA; $p<0.001, \chi^{2}$ test. $G$, Individual traces and time course of a representative experiment in which URB597 (URB; FAAH inhibitor, $1 \mu \mathrm{m}$ ) was applied to a male slice. URB597 had no overall effect on IPSC amplitude in males. $\boldsymbol{H}$, Individual traces and time course of a representative experiment in which URB597 was applied to a female slice. URB597 often decreased IPSC amplitude in females. $I$, Normalized IPSC amplitude for all cells recorded from both sexes in the presence of URB597 showing a significant sex difference in response rate. Of 17 cells recorded in males, only one showed a URB597-induced decrease in IPSC amplitude, compared with 10 of 18 cells recorded in females; $p<0.01, \chi^{2}$ test. J, Group PPR data for all URB597-responsive cells in females $(n=10) ;{ }^{* *} p<0.01$, paired $t$ test. Calibration: $25 \mathrm{pA}, 25 \mathrm{~ms}$.
} 
$\mathrm{IP}_{3} \mathrm{R}$ in hippocampal cell membranes of both sexes, but that this complex is regulated by E2 only in females. Likely related to this difference, E2 stimulates $\mathrm{IP}_{3}$ synthesis much more strongly in females than in males. Overall, our results suggest a model in which, in females specifically, E2 acutely suppresses inhibition by promoting an interaction between $\mathrm{ER} \alpha$ and mGluR1, which activates PLC to generate $\mathrm{IP}_{3}$ and stimulate $\mathrm{Ca}^{2+}$ release via the $\mathrm{IP}_{3} \mathrm{R}$, leading to AEA mobilization from postsynaptic cells (Fig. 9). We also found evidence of a sex difference in eCB signaling independently of E2. Inhibition of FAAH, the enzyme that degrades AEA, suppressed inhibition in more than half of experiments in females but had very little effect in males. This indicates that a substantial fraction of inhibitory synapses in females, but not in males, is under tonic suppression by AEA or another FAAH-sensitive eCB. These findings have implications for understanding how eCB-dependent physiological and behavioral responses differ between the sexes.

\section{Sex differences in modulation of mGluR signaling}

All animals in our study were gonadectomized as adults before being used for experiments, making it very unlikely that the sex differences we observed depend on circulating gonadal hormones. Rather, parallels between our experiments and previous studies in cell culture suggest that the sex difference in E2 stimulation of ER $\alpha-\mathrm{mGluR} 1$ signaling arises through developmental programming by perinatal hormones. Before our study, Boulware et al. (2005) demonstrated that E2 acutely stimulates CREB phosphorylation in hippocampal cultures from female but not male rats and that this depends on an interaction between membrane-associated $\operatorname{ER} \alpha$ and mGluR1 that occurs in the absence of an increase in released glutamate. Importantly, this group later showed that E2 responsiveness of neurons from females can be eliminated by injection of E2 or testosterone (T; which can be converted to $\mathrm{E} 2$ in the brain) on postnatal day 0 (P0) and P1, before cultures were prepared on P2 (Meitzen et al., 2012). This suggests that the sex difference in E2 modulation of mGluR1 signaling is a classical "organizational" effect of gonadal hormones, in which early life exposure to E2 or T masculinizes the brain and the lack of E2 or T results in feminization. The first demonstrations of organizational hormone effects focused on sex behavior (Phoenix et al., 1959; Feder and Whalen, 1965). Meitzen et al. (2012) extended this concept to acute E2 signaling at a molecular level, and our study demonstrates that the sex difference persists into adulthood to influence the susceptibility of synapses to modulation by E2. Thus, once the developmental programming of this molecular response is established as male or female early in life, the sex difference is maintained through puberty and even in the absence of circulating gonadal hormones.

It is important to note that we observed a sex difference in E2 modulation of mGluR signaling but not in mGluR signaling independently of E2. For example, we found that DHPG activation of group I mGluRs stimulates $\mathrm{IP}_{3}$ synthesis equivalently in hippocampal slices from males and females, indicating no sex difference in mGluR1 to PLC signaling. In contrast, indirect activation of mGluR1 by E2 (presumably via ER $\alpha$ ) stimulated mGluR1dependent $\mathrm{IP}_{3}$ synthesis to a much greater extent in females than in males. Again, this parallels results from Meitzen et al. (2012) who found that, unlike the effects of E2, DHPG-induced CREB phosphorylation in female hippocampal cultures was not eliminated by early $\mathrm{T}$ treatment. Together, these observations indicate that the sex difference in E2 signaling likely arises at the level of $\mathrm{ER} \alpha$ activation of mGluR1.
Our co-IP results are consistent with a sex difference in E2$\mathrm{ER} \alpha$ activation of mGluR1. We found no differences between males and females in overall levels of ER $\alpha$, mGluR1a, IP3R, or in the interaction of these molecules under basal conditions (i.e., in vehicle-treated slices). We considered the possibility that Homer$1 \mathrm{~b} / \mathrm{c}$, which tethers mGluRs to the $\mathrm{IP}_{3} \mathrm{R}$, might differ between males and females, but again we found no evidence of a sex difference in levels of Homer-1b/c or its ability to interact with $\mathrm{IP}_{3} \mathrm{R}$. In each set of experiments, sex differences were detected specifically in E2 modulation of molecular interactions.

These results suggest two not mutually exclusive possibilities to explain sex-specific E2 modulation of mGluR signaling. First, there may be an additional, yet-to-be-identified, E2-sensitive factor that participates in complex with $\mathrm{ER} \alpha$ and mGluR1 and that promotes interaction between them and/or downstream $\mathrm{G} \alpha$ q signaling. Alternatively, differences in membrane targeting of ER $\alpha$ and/or mGluR1 that are not detectable in co-IP experiments may lead to differential modulation and/or downstream signaling. Consistent with this idea, Boulware et al. (2007) have shown in hippocampal cultures that manipulation of caveolin proteins that target $\mathrm{ER} \alpha$ to membranes or of palmitoyltransferases that are required for $\mathrm{ER} \alpha$ anchoring to membranes via S-palmitoylation (Meitzen et al., 2013; Tabatadze et al., 2013) can influence acute E2 signaling through membrane-associated ER $\alpha$. Additional studies will be required to investigate whether sex differences in these factors, or their E2 sensitivity, account for sex differences in E2 modulation of mGluR signaling in adulthood.

\section{mGluR1-dependent eCB signaling in females}

Previous electrophysiological studies using selective antagonists for mGluR1 and mGluR5 indicated that E2-induced suppression of inhibition depends on mGluR1, not mGluR5 (Huang and Woolley, 2012). In the current study, results of co-IP experiments corroborated this by showing that $\mathrm{ER} \alpha$ interacts with mGluR1a but not mGluR5. Previous studies in the hypothalamus (Dewing et al., 2007) and hippocampus (Boulware et al., 2013) also have shown that ER $\alpha$ interacts with mGluRla. However, the mGluR1 dependence of E2 suppression of inhibition in CA1 pyramidal cells is surprising because both DHPG-induced suppression of inhibition (Ohno-Shosaku et al., 2002) and synaptically induced mGluR-dependent iLTD (Chevaleyre and Castillo, 2003; Izumi and Zorumski, 2012) in CA1 have been shown to depend on mGluR5. We confirmed that the inhibitory synapses suppressed by $\mathrm{E} 2$ are the same as those suppressed by group I mGluR activation and by eCBs through mutual occlusion experiments with E2 and DHPG or TBF stimulation to induce iLTD.

Several distinctions between our experiments and previous studies may help to explain the differences. First, other studies of mGluR-dependent regulation of IPSCs have typically focused on dendritic IPSCs, whereas we recorded perisomatic IPSCs. Thus, it is possible that the mGluR involved in modulating intracellular signaling at the soma differs from that in the dendrites. Consistent with this, mGluR1-selective, but not mGluR5-selective, antagonists block DHPG-induced somatic $\mathrm{Ca}^{2+}$ transients in CA1 pyramidal cells, whereas mGluR5 and not mGluR1 antagonists block DHPG-induced potentiation of NMDA-evoked currents (Mannaioni et al., 2001). Similarly, mGluR1 and mGluR5 antagonists each only partially block DHPG-induced suppression of IPSCs evoked by a bipolar stimulating electrode, which likely activated both somatic and dendritic inputs (Mannaioni et al., 2001). It is also possible that differences are related to the age or sex of animals used. Most electrophysiological studies of IPSC modulation use animals younger than in our experiments (e.g., 
P10-P12 in the study by Ohno-Shosaku et al., 2002; P21-P28 in the study by Chevaleyre and Castillo, 2003) and only rarely indicate the sex of animals used.

The cellular location of mGluR1 that mediates E2-induced suppression of inhibition is uncertain. The simplest explanation of our results involves mGluR1 in CA1 pyramidal cells at or near the inhibitory synapses modulated by E2. Although immunostaining studies find little evidence of mGluR1 labeling in CA1 pyramidal cells (Baude et al., 1993; Petralia et al., 1997), our single-cell nested PCR analysis indicated that $\sim 50 \%$ of CA1 pyramidal cells contain mGluR1a mRNA; mGluR5 was detected in a greater fraction, $86 \%$. Although the abundance of mGluR1a mRNA in each cell cannot be determined with this approach, nor can we determine whether mRNA is translated into protein, PCR results indicate that a subset of CA1 pyramidal cells expresses mGluR1. Alternatively, it is also possible that $\mathrm{E} 2-\mathrm{ER} \alpha-\mathrm{mGluR} 1$ signaling in another cell type, such as astrocytes (Kuo et al., 2009) or stratum oriens interneurons (Ferraguti et al., 2004), might lead to $\mathrm{eCB}$ production in $\mathrm{CA} 1$ pyramidal cells.

\section{Sex difference in tonic eCB signaling}

Our experiments also indicate a sex difference in hippocampal eCB signaling independently of E2 regulation. Specifically, we found that FAAH inhibition suppressed inhibitory synapses in females, indicating tonic AEA production, but had no effect in males. This is potentially relevant to the development of therapeutics that target AEA metabolism. For example, FAAH inhibitors have been considered for cannabis withdrawal and in regulation of fear responses in clinical trials (ClinicalTrials.gov). That FAAH inhibitors affect synapses differently in males versus females provides a strong rationale for considering sex as a variable in clinical studies that investigate $\mathrm{eCB}$ regulation of physiological or behavioral responses.

\section{References}

Alger BE (2004) Endocannabinoids and their implications for epilepsy. Epilepsy Curr 4:169-173. CrossRef Medline

Altemus M, Sarvaiya N, Neill Epperson C (2014) Sex differences in anxiety and depression clinical perspectives. Front Neuroendocrinol 35:320-330. CrossRef Medline

Atkinson HC, Leggett JD, Wood SA, Castrique ES, Kershaw YM, Lightman SL (2010) Regulation of the hypothalamic-pituitary-adrenal axis circadian rhythm by endocannabinoids is sexually diergic. Endocrinology 151: 3720-3727. CrossRef Medline

Baude A, Nusser Z, Roberts JD, Mulvihill E, McIlhinney RA, Somogyi P (1993) The metabotropic glutamate receptor (mGluR1 alpha) is concentrated at perisynaptic membrane of neuronal subpopulations as detected by immunogold reaction. Neuron 11:771-787. CrossRef Medline

Boulware MI, Weick JP, Becklund BR, Kuo SP, Groth RD, Mermelstein PG (2005) Estradiol activates group I and II metabotropic glutamate receptor signaling, leading to opposing influences on cAMP response elementbinding protein. J Neurosci 25:5066-5078. CrossRef Medline

Boulware MI, Kordasiewicz H, Mermelstein PG (2007) Caveolin proteins are essential for distinct effects of membrane estrogen receptors in neurons. J Neurosci 27:9941-9950. CrossRef Medline

Boulware MI, Heisler JD, Frick KM (2013) The memory-enhancing effects of hippocampal estrogen receptor activation involve metabotropic glutamate receptor signaling. J Neurosci 33:15184-15194. CrossRef Medline

Caraguel CG, Stryhn H, Gagné N, Dohoo IR, Hammell KL (2011) Selection of a cutoff value for real-time polymerase chain reaction results to fit a diagnostic purpose: analytical and epidemiologic approaches. J Vet Diagn Invest 23:2-15. CrossRef Medline

Castillo PE, Younts TJ, Chávez AE, Hashimotodani Y (2012) Endocannabinoid signaling and synaptic function. Neuron 76:70-81. CrossRef Medline

Chevaleyre V, Castillo PE (2003) Heterosynaptic LTD of hippocampal GABAergic synapses: a novel role of endocannabinoids in regulating excitability. Neuron 38:461-472. CrossRef Medline
Citri A, Pang ZP, Südhof TC, Wernig M, Malenka RC (2012) Comprehensive qPCR profiling of gene expression in single neuronal cells. Nat Protoc 7:118-127. CrossRef Medline

Cravatt BF, Giang DK, Mayfield SP, Boger DL, Lerner RA, Gilula NB (1996) Molecular characterization of an enzyme that degrades neuromodulatory fatty-acid amides. Nature 384:83-87. CrossRef Medline

Dewing P, Boulware MI, Sinchak K, Christensen A, Mermelstein PG, Micevych P (2007) Membrane estrogen receptor-alpha interactions with metabotropic glutamate receptor 1a modulate female sexual receptivity in rats. J Neurosci 27:9294-9300. CrossRef Medline

Di Marzo V, Fontana A, Cadas H, Schinelli S, Cimino G, Schwartz JC, Piomelli D (1994) Formation and inactivation of endogenous cannabinoid anandamide in central neurons. Nature 372:686-691. CrossRef Medline

El-Hassar L, Hagenston AM, D’Angelo LB, Yeckel MF (2011) Metabotropic glutamate receptors regulate hippocampal CAl pyramidal neuron excitability via $\mathrm{Ca}^{2+}$ wave-dependent activation of SK and TRPC channels. J Physiol 589:3211-3229. CrossRef Medline

Feder HH, Whalen RE (1965) Feminine behavior in neonatally castrated and estrogen-treated male rats. Science 147:306-307. CrossRef Medline

Ferraguti F, Cobden P, Pollard M, Cope D, Shigemoto R, Watanabe M, Somogyi P (2004) Immunolocalization of metabotropic glutamate receptor $1 \alpha(\mathrm{mGluR} 1 \alpha)$ in distinct classes of interneurons in the CA1 region of rat hippocampus. Hippocampus 14:193-215. CrossRef Medline

Fino E, Paille V, Cui Y, Morera-Herreras T, Deniau JM, Venance L (2010) Distinct coincidence detectors govern the corticostriatal spike timingdependent plasticity. J Physiol 588:3045-3062. CrossRef Medline

Furuichi T, Yoshikawa S, Miyawaki A, Wada K, Maeda N, Mikoshiba K (1989) Primary structure and functional expression of the inositol 1,4,5trisphosphate-binding protein P400. Nature 342:32-38. CrossRef Medline

Hájos N, Kathuria S, Dinh T, Piomelli D, Freund TF (2004) Endocannabinoid transport tightly controls 2-arachidonoyl glycerol actions in the hippocampus: effects of low temperature and the transport inhibitor AM404. Eur J Neurosci 19:2991-2996. CrossRef Medline

Hart SA, Snyder MA, Smejkalova T, Woolley CS (2007) Estrogen mobilizes a subset of estrogen receptor-alpha-immunoreactive vesicles in inhibitory presynaptic boutons in hippocampal CA1. J Neurosci 27:2102-2111. CrossRef Medline

Hashimotodani Y, Ohno-Shosaku T, Tsubokawa H, Ogata H, Emoto K, Maejima T, Araishi K, Shin HS, Kano M (2005) Phospholipase Cbeta serves as a coincidence detector through its $\mathrm{Ca} 2+$ dependency for triggering retrograde endocannabinoid signal. Neuron 45:257-268. CrossRef Medline

Hashimotodani Y, Ohno-Shosaku T, Kano M (2007) Ca(2+)-assisted receptor-driven endocannabinoid release: mechanisms that associate presynaptic and postsynaptic activities. Curr Opin Neurobiol 17:360 365. CrossRef Medline

Hayashi MK, Tang C, Verpelli C, Narayanan R, Stearns MH, Xu RM, Li H, Sala C, Hayashi Y (2009) The postsynaptic density proteins Homer and Shank form a polymeric network structure. Cell 137:159-171. CrossRef Medline

Herson PS, Palmateer J, Hurn PD (2013) Biological sex and mechanisms of ischemic brain injury. Transl Stroke Res 4:413-419. CrossRef Medline

Hill MN, Patel S (2013) Translational evidence for the involvement of the endocannabinoid system in stress-related psychiatric illnesses. Biol Mood Anxiety Disord 3:19. CrossRef Medline

Hu JH, Yang L, Kammermeier PJ, Moore CG, Brakeman PR, Tu J, Yu S, Petralia RS, Li Z, Zhang PW, Park JM, Dong X, Xiao B, Worley PF (2012) Presol dynamically regulates group I metabotropic glutamate receptors. Nat Neurosci 15:836-844. CrossRef Medline

Huang GZ, Woolley CS (2012) Estradiol acutely suppresses inhibition in the hippocampus through a sex-specific endocannabinoid and mGluRdependent mechanism. Neuron 74:801-808. CrossRef Medline

Izumi Y, Zorumski CF (2012) NMDA receptors, mGluR5, and endocannabinoids are involved in a cascade leading to hippocampal long-term depression. Neuropsychopharmacology 37:609-617. CrossRef Medline

Jin DZ, Guo ML, Xue B, Fibuch EE, Choe ES, Mao LM, Wang JQ (2013) Phosphorylation and feedback regulation of metabotropic glutamate receptor 1 by calcium/calmodulin-dependent protein kinase II. J Neurosci 33:3402-3412. CrossRef Medline

Kammermeier PJ (2008) Endogenous homer proteins regulate metabo- 
tropic glutamate receptor signaling in neurons. J Neurosci 28:8560 -8567. CrossRef Medline

Katona I, Sperlágh B, Sík A, Käfalvi A, Vizi ES, Mackie K, Freund TF (1999) Presynaptically located CB1 cannabinoid receptors regulate GABA release from axon terminals of specific hippocampal interneurons. J Neurosci 19:4544-4558. Medline

Katona I, Urbán GM, Wallace M, Ledent C, Jung KM, Piomelli D, Mackie K, Freund TF (2006) Molecular composition of the endocannabinoid system at glutamatergic synapses. J Neurosci 26:5628-5637. CrossRef Medline

Kim J, Alger BE (2004) Inhibition of cyclooxygenase-2 potentiates retrograde endocannabinoid effects in hippocampus. Nat Neurosci 7:697698. CrossRef Medline

Kosinski CM, Standaert DG, Testa CM, Penney JB Jr, Young AB (1998) Expression of metabotropic glutamate receptor 1 isoforms in the substantia nigra pars compacta of the rat. Neuroscience 86:783-798. CrossRef Medline

Kramár EA, Chen LY, Brandon NJ, Rex CS, Liu F, Gall CM, Lynch G (2009) Cytoskeletal changes underlie estrogen's acute effects on synaptic transmission and plasticity. J Neurosci 29:12982-12993. CrossRef Medline

Kuo J, Hariri OR, Bondar G, Ogi J, Micevych P (2009) Membrane estrogen receptor-alpha interacts with metabotropic glutamate receptor type la to mobilize intracellular calcium in hypothalamic astrocytes. Endocrinology 150:1369-1376. CrossRef Medline

Maione S, Costa B, Di Marzo V (2013) Endocannabinoids: a unique opportunity to develop multitarget analgesics. Pain 1:S87-S93. CrossRef Medline

Mannaioni G, Marino MJ, Valenti O, Traynelis SF, Conn PJ (2001) Metabotropic glutamate receptors 1 and 5 differentially regulate CA1 pyramidal cell function. J Neurosci 21:5925-5934. Medline

Meitzen J, Grove DD, Mermelstein PG (2012) The organizational and aromatization hypotheses apply to rapid, nonclassical hormone action: neonatal masculinization eliminates rapid estradiol action in female hippocampal neurons. Endocrinology 153:4616-4621. CrossRef Medline

Meitzen J, Luoma JI, Boulware MI, Hedges VL, Peterson BM, Tuomela K, Britson KA, Mermelstein PG (2013) Palmitoylation of estrogen receptors is essential for neuronal membrane signaling. Endocrinology 154: 4293-4304. CrossRef Medline

Milner TA, McEwen BS, Hayashi S, Li CJ, Reagan LP, Alves SE (2001) Ultrastructural evidence that hippocampal alpha estrogen receptors are located at extranuclear sites. J Comp Neurol 429:355-371. CrossRef Medline

Nakamura T, Nakamura K, Lasser-Ross N, Barbara JG, Sandler VM, Ross WN (2000) Inositol 1,4,5-trisphosphate (IP3)-mediated Ca2 + release evoked by metabotropic agonists and backpropagating action potentials in hippocampal CA1 pyramidal neurons. J Neurosci 20:8365-8376. Medline

Ohno-Shosaku T, Shosaku J, Tsubokawa H, Kano M (2002) Cooperative endocannabinoid production by neuronal depolarization and group I metabotropic glutamate receptor activation. Eur J Neurosci 15:953-961. CrossRef Medline

Petralia RS, Wang YX, Singh S, Wu C, Shi L, Wei J, Wenthold RJ (1997) A monoclonal antibody shows discrete cellular and subcellular localizations of mGluR1 alpha metabotropic glutamate receptors. J Chem Neuroanat 13:77-93. CrossRef Medline

Phoenix CH, Goy RW, Gerall AA, Young WC (1959) Organizing action of prenatally administered testosterone propionate on the tissues mediating mating behavior in the female guinea pig. Endocrinology 65:369-382. CrossRef Medline

Price CJ, Cauli B, Kovacs ER, Kulik A, Lambolez B, Shigemoto R, Capogna M (2005) Neurogliaform neurons form a novel inhibitory network in the hippocampal CA1 area. J Neurosci 25:6775-6786. CrossRef Medline

Reich CG, Taylor ME, McCarthy MM (2009) Differential effects of chronic unpredictable stress on hippocampal CB1 receptors in male and female rats. Behav Brain Res 203:264-269. CrossRef Medline

Ronesi J, Gerdeman GL, Lovinger DM (2004) Disruption of endocannabinoid release and striatal long-term depression by postsynaptic blockade of endocannabinoid membrane transport. J Neurosci 24:1673-1679. CrossRef Medline

Savic I, Engel J Jr (2014) Structural and functional correlates of epileptogenesis-does gender matter? Neurobiol Dis 70:69-73. CrossRef Medline

Shigemoto R, Nakanishi S, Mizuno N (1992) Distribution of the mRNA for a metabotropic glutamate receptor (mGluR1) in the central nervous system: an in situ hybridization study in adult and developing rat. J Comp Neurol 322:121-135. CrossRef Medline

Smejkalova T, Woolley CS (2010) Estradiol acutely potentiates hippocampal excitatory synaptic transmission through a presynaptic mechanism. J Neurosci 30:16137-16148. CrossRef Medline

Tabatadze N, Smejkalova T, Woolley CS (2013) Distribution and posttranslational modification of synaptic $\mathrm{ER} \alpha$ in the adult female rat hippocampus. Endocrinology 154:819-830. CrossRef Medline

Tanimura A, Yamazaki M, Hashimotodani Y, Uchigashima M, Kawata S, Abe M, Kita Y, Hashimoto K, Shimizu T, Watanabe M, Sakimura K, Kano M (2010) The endocannabinoid 2-arachidonoylglycerol produced by diacylglycerol lipase alpha mediates retrograde suppression of synaptic transmission. Neuron 65:320-327. CrossRef Medline

Tu JC, Xiao B, Yuan JP, Lanahan AA, Leoffert K, Li M, Linden DJ, Worley PF (1998) Homer binds a novel proline-rich motif and links group 1 metabotropic glutamate receptors with IP3 receptors. Neuron 21:717726. CrossRef Medline

van der Stelt M, Trevisani M, Vellani V, De Petrocellis L, Schiano Moriello A, Campi B, McNaughton P, Geppetti P, Di Marzo V (2005) Anandamide acts as an intracellular messenger amplifying Ca2+ influx via TRPV1 channels. EMBO J 24:3026-3037. CrossRef Medline

Werling DM, Geschwind DH (2013) Sex difference in autism spectrum disorders. Curr Opin Neurol 26:146-153. CrossRef Medline

Wiley JL, Kendler SH, Burston JJ, Howard DR, Selley DE, Sim-Selley LJ (2008) Antipsychotic-induced alterations in CB1 receptor-mediated G-protein signaling and in vivo pharmacology in rats. Neuropharmacology 55:1183-1190. CrossRef Medline

Younts TJ, Chevaleyre V, Castillo PE (2013) CA1 pyramidal cell theta-burst firing triggers endocannabinoid-mediated long-term depression at both somatic and dendritic inhibitory synapses. J Neurosci 33:13743-13757. CrossRef Medline

Yu YC, Cao LH, Yang XL (2006) Modulation by brain natriuretic peptide of GABA receptors on rat retinal ON-type bipolar cells. J Neurosci 26:696707. CrossRef Medline

Zanettini C, Panlilio LV, Alicki M, Goldberg SR, Haller J, Yasar S (2011) Effects of endocannabinoid system modulation on cognitive and emotional behavior. Front Behav Neurosci 5:57. CrossRef Medline 